\title{
Studying the implementation of the Water Framework Directive in Europe: a meta-analysis of 89 journal articles
}

\author{
Blandine Boeuf ${ }^{1,2}$ and Oliver Fritsch ${ }^{1,3}$
}

\begin{abstract}
The Water Framework Directive (WFD) is arguably the most ambitious piece of European Union (EU) legislation in the field of water. The directive defines a general framework for integrated river basin management in Europe with a view to achieving "good water status" by 2015. Institutional novelties include, among others, water management at hydrological scales, the involvement of nonstate actors in water planning, and various economic principles, as well as a common strategy to support EU member states during the implementation of the directive. More than 15 years after the adoption of the WFD, and with the passing of an important milestone, 2015, we believe it is time for an interim assessment. This article provides a systematic review of existing scholarship on WFD implementation. We identify well-documented areas of research, describe largely unchartered territories, and suggest avenues for future studies. Methodologically, we relied on a meta-analysis. Based on a codebook of more than 35 items, we analyzed 89 journal articles reporting on the implementation of the directive in EU member states. Our review is organized around three major themes. The first is "who, when, and where"; we explore publication patterns, thereby looking into authors, timelines, and target journals. The second is "what"; we analyze the object of study in our source articles with a particular focus on case study countries, policy levels, the temporal stage of WFD implementation, and if the directive was not studied in its entirety, the aspect of the WFD that received scholarly attention. The third is "how," i.e., theoretical and methodological choices made when studying the WFD.
\end{abstract}

Key Words: EU environmental policy; meta-analysis; policy implementation; systematic review; Water Framework Directive; water governance

\section{INTRODUCTION}

The Water Framework Directive (WFD), adopted in 2000, is arguably the most ambitious piece of European Union (EU) legislation in the field of water. The directive defines a general framework for integrated river basin management in Europe with a view to achieving "good water status" by 2015. Institutional novelties include, among others, water planning at hydrological rather than administrative scales, the involvement of nonstate actors, various economic principles as reflected in tools such as cost-effectiveness analysis, and a common strategy to support EU member states implementing the directive (Kallis and Butler 2001, Kaika 2003, Adshead 2004, Grimeaud 2004).

Not surprisingly, the WFD has attracted wide scholarly attention. At the time of writing, the Social Science Citation Index lists no less than 728 articles referring to the directive in the title or the abstract. Researchers from disciplines as diverse as political science, legal studies, economics, and sociology have studied the directive. Interdisciplinary approaches are legion. Arguably, not all of those $700+$ articles are "spot on," but there is no denying that the WFD is a prime topic for social scientists working on water resources.

However, as much as we know about the WFD and its implementation in Europe, attempts to map existing scholarship are scarce. Previous research provides a checkered pattern of single case studies or small-n comparative work, often within one country. Almost 15 years after the adoption of the directive, and with the passing of an important milestone, 2015, we believe it is time for an interim assessment. Providing a systematic review of existing scholarship, this article identifies well-documented areas of research, describes largely unchartered territories, and suggests avenues for future studies. In doing so, this survey is the first to provide a comprehensive and systematic review of scholarship on WFD implementation in Europe.

Our review is organized around three major themes. The first theme is "who, when, and where"; we explore publication patterns, thereby looking into authors, timelines, and target journals. The second is "what"; we analyze the object of study in our source articles with a particular focus on case study countries, policy levels, the temporal stage of WFD implementation, and if the directive was not studied in its entirety, the aspect of the WFD that received scholarly attention. The third is "how," i.e., theoretical and methodological choices made when studying the WFD.

That being said, we would like to make plain what we are not doing. We examined the nature of research questions asked, and we report on theory and methods. However, we do not provide answers given to those questions. In other words, we make no attempt to aggregate research findings to present a broader picture of WFD implementation in Europe. Scholars interested in accumulated data may consult the four official implementation reports published by the European Commission (2007, 2009a, $2012 a, 2015)$ and work carried out by Kanakoudis and colleagues (Kanakoudis and Tsitsifli 2010, Kanakoudis et al. 2015); the authors focus on Greece, but also use European Commission data to report on WFD implementation in the EU27. We do not contribute to this discussion.

Methodologically, we relied on meta-analysis. Meta-analytical approaches aggregate in a systematic fashion knowledge from

${ }^{1}$ water@leeds, University of Leeds, ${ }^{2}$ Sustainability Research Institute, School of Earth and Environment, University of Leeds, ${ }^{3}$ School of Geography, University of Leeds 
source texts, thereby using partly or fully quantitative aggregation methods. Initially developed to make causal statements about the relationship between two or more variables across a range of source studies, i.e., to answer a specific research question, metaanalysis is increasingly being used to summarize an area of research as a whole. Such systematic reviews then do not explore questions of causality, but provide a thorough overview of a specific body of literature with regard to the research questions asked, theoretical approaches used, research designs and methods chosen, and jurisdictions and time periods covered (Poteete and Ostrom 2008, Exadaktylos and Radaelli 2009, Lam et al. 2012). Our article reflects the latter ambition. We examined 89 articles, published in English-language academic journals, that explore empirically and from a social science perspective the implementation of the WFD in EU member states. To this end, we extracted information on more than 35 dimensions from each source article.

\section{THE WATER FRAMEWORK DIRECTIVE}

Water is one of the oldest and most heavily regulated areas in EU environmental policy, covering issues such as drinking water, waste water, and groundwater. However, the sector had always been plagued, since the adoption of the first directives at European level in the early 1970s, by serious implementation deficits and a lack of policy effectiveness. Three factors were of particular importance: low acceptance rates on the part of target groups, the mismatch between ecological (river basins) and political (political and administrative institutions) scales, and the fact that standards-based approaches regulating individual or families of substances completely ignored the problem of synergetic ecological effects (Jordan 1999, Grant et al. 2000, Kallis 2005).

Through the WFD, adopted in December 2000, the EU introduced a promising set of political instruments to tackle the challenges that have long characterized EU water management (Kallis and Butler 2001). Principally, the WFD aims to develop an "integrated community policy on water" (Preamble 3 WFD) by bringing together all water resources, uses, values, stakeholders, and relevant decision-making levels under a common legal regime (European Commission 2003:5-6). To this end, the directive creates a framework for existing policies, repeals others, and provides a reference point for subsequent legislation, such as the new Groundwater Directive.

Good surface water status as well as good groundwater status were the key objectives to be achieved by 2015. Additionally, member states are required to protect existing water bodies from deterioration. For surface waters, the assessment of the status is based on a measurement scale that rates biological and hydromorphological characteristics as high, good, moderate, poor, and bad, and chemical characteristics as good and fail. The directive thus breaks new ground by complementing chemical water quality assessments with the more general assessment of ecological quality. In particular, a surface water body is of good quality if there are only minor departures from the quality of pristine water bodies with minimal anthropogenic impact. Groundwater is classified as good or poor, based on its chemical and its quantitative status. Artificial or heavily modified water bodies such as canals are to achieve at least good ecological potential, which is as close as possible to good status. The achievement of the 2015 water policy goals may be delayed up to 2027 or even lowered to a less stringent objective under reference to natural conditions, technical feasibility, or disproportionate costs.

Taking into account that the existing body of EU water legislation already consists of far-reaching substantive measures, the WFD puts a high premium on the procedural side of water management. Five novelties are crucial:

River basin districts: Recognizing that water is not static and that water bodies exist across political and administrative boundaries, member states are required to manage water at hydrological scales. To this end, River Basin Districts (RBDs) shall be established, respective management bodies shall be created, or if member states elect to remain within their existing administrative structures, collaboration shall be ensured between jurisdictions to manage river basins.

River basin management planning: The WFD planning process consists of eight steps: assessment of water status, characterization of physical and societal pressures on water bodies, designation of artificial and heavily modified water bodies, determination of water bodies at risk, revision of an existing River Basin Management Plan, adoption of a Programme of Measures to specify concrete actions, implementation of those two documents, monitoring, and review. This sequence of activities is to be repeated every six years.

Public participation: Engagement activities involve three components: information, consultation, and active involvement. Information requirements mainly include obligations to make status and risk assessments, background information, and maps publicly available. In terms of consultation, member states must organize three rounds of public comment during the preparation of River Basin Management Plans. Active involvement describes a more intense mode of participation and may include planning in small groups and face-to-face.

Economic analysis: The directive encourages decision makers to consider economic principles at various stages of the planning process. This may involve cost-benefit analysis to justify exemptions, cost-effectiveness tests and other analyses to identify suitable management options, and pricing and cost-recovery mechanisms to change water consumption patterns.

Policy integration: To achieve the directive's policy goals, member state authorities are required to ensure policy integration not only within the water sector (for instance, integration of surface water and groundwater), but also within adjacent fields, such as flood control, forestry, or climate change. Rather than being a specific governance tool, policy integration represents a guiding principle of WFD water management.

These five components are held together by a strict timetable. Adopted in 2000, the directive required EU member states to transpose it into national law within three years. Until 2009, member states were then obliged to establish RBDs, to designate or create new management authorities at the river basin level, to identify and map water bodies, to establish monitoring networks, and to adopt a first River Basin Management Plan and Programme of Measures for each RBD. From 2009 onwards, member states would then reinitiate the above-mentioned sequence of management activities every six years. 
All member states engage, though in varying degrees, in the Common Implementation Strategy (CIS). Established by the European Commission and the member states in 2001, the CIS brings together domestic water practitioners, regulators, and experts so as to report best practices and encourage mutual learning. In terms of organization, CIS participants collaborate in working groups that reflect key challenges to WFD implementation, for instance, on monitoring, groundwater, heavily modified water bodies, or economics. CIS outputs include more than 30 legally nonbinding implementation guidelines that provide best-practice cases, advice for specific water management problems, and benchmarks for good water governance. The CIRCABC website (Communication and Information Resource Centre for Administrations, Businesses and Citizens; https:// circabc.europa.eu/faces/jsp/extension/wai/navigation/container.jsp) serves as an important coordination and communication device.

Who implements the directive? The WFD is a legally binding EU policy, which is why all member states are obliged to transpose the directive and put it into practice. EU candidate states may implement parts of the directive as part of their accession agreements; likewise, associated countries such as Norway and Switzerland may adopt key features of WFD water management.

To sum up, all EU member states implement the WFD. In the past nine years, those countries may have engaged in at least six overlapping, yet conceptually distinct, activities: water management at hydrological scales, the preparation of River Basin Management Plans and Programmes of Measures, public participation, economic analysis, and policy integration, plus participation in CIS working groups at the EU level. However, there is also a temporal dimension: We distinguish the preparation period between 2003 and 2009, characterized by institution building and the preparation of the first set of River Basin Management Plans and Programmes of Measures, from the first management cycle, from 2009 to 2015. This perspective leaves aside the transposition into national law (up until 2003).

Let us now undertake a thought experiment and describe WFD implementation as a 3-dimensional space, consisting of 28 (countries) $\times 6$ (activities) $\times 2$ (time periods) = at least 336 cells that could be filled with exciting data. Importantly, these 336 cells are not mere data points, but spaces that, each for itself, may tell complex stories about actors, ideologies, and institutions. To illustrate, one cell would contain information on public participation in France during the first management cycle. We appreciate that this thought experiment is somewhat crude, but we may still think of the above-mentioned space as a container subsequently to be filled with intriguing findings from WFD scholarship. Research priorities are distributed unevenly with regards to countries, WFD requirements, and time periods. This leads us to suggest that some sectors of this 3-dimensional space are densely populated, whereas others remain largely unchartered terrain. We are not necessarily arguing that the research community should first and foremost seek to fill those 336 cells. After all, scholars may legitimately elect to use WFD implementation as a case study to further an agenda unrelated to the implementation of the directive. However, scholars wishing to contribute to scholarly debates on WFD implementation, and on EU policy implementation more broadly, may use this image as a device to reflect on areas of research that are well documented and on those that are understudied or widely ignored.

\section{STUDYING EU POLICY IMPLEMENTATION}

The previous section outlined a purely descriptive research program: What requirements could or should be taken into account in WFD implementation research? However, to explain the implementation patterns described in the matrix above, one would have to consider a set of independent variables. For this, one would have to make use of one of the explanatory frameworks developed in the EU policy implementation and Europeanization literature.

This literature did, in its early days, borrow much from its transatlantic counterpart in the United States (Pressman and Wildavsky 1984, DeLeon 1999, Hill and Hupe 2002). In doing so, the European community reproduced quite a few shortcomings characteristic of the U.S. literature, in particular its tendency to generate endless lists of potential causal factors. To recall, O'Toole (1986) counted more than 300 variables discussed in the literature. Since then, much progress has been made. We discuss three leading approaches in Europeanization research: the goodness-of-fit approach, the actor-based approaches, and the worlds-ofcompliance approach.

Goodness-of-fit approach: Relying on historical institutionalism, this approach argues that existing paths are resistant to change. EU policy implementation will be smooth if European requirements can be accommodated within current domestic paths, yet will be delayed or incorrectly implemented if they require substantive changes. To assess the degree of suitability and to predict compliance patterns, scholars compare European requirements and domestic policies. Often, authors distinguish policy fit, emphasising the compatibility of domestic and European policies, from institutional fit, highlighting the congruity between domestic institutions and institutional requirements of EU directives (Börzel 1999).

Increasingly, however, empirical work disconfirms the argument (Haverland 2000, Falkner et al. 2005). This is because the hypothesis is "rather static in nature" (Mastenbroek 2005:1110). Plausibly, domestic actors are not necessarily interested in preserving the status quo. Instead, they may want to change existing policies and institutions and thus utilize the EU for domestic purposes. In response to these criticisms, proponents of the goodness-of-fit perspective added a number of auxiliary variables to the initial argument (Risse et al. 2001, Thomson 2007, Hartlapp 2009). However, these amendments lead to a theoretically elegant, though empirically inconclusive, hypothesis that makes the notion of goodness of fit overly complex and, because of its ad hoc character, does not allow for ex ante hypothesising.

Actor-based approaches: Other scholars, in contrast, abandoned the structuralist core of the goodness-of-fit argument entirely and suggested examining actors, interests, and beliefs directly. From a rational-choice perspective, this includes exchange, bargaining, and principal-agent models (Haverland and Romeijn 2007, Kaeding 2008). Sociological-institutionalist accounts instead theorize compliance with EU directives as a result of socialization, persuasion, and learning processes (Checkel 2001).

Worlds-of-compliance approach: Falkner et al. (2005) and Falkner and Treib (2008) argue that the substance of a particular EU policy is of little relevance for EU policy implementation. Instead, the authors focus on national compliance cultures, i.e., general 
attitudes toward the rule of law and compliance with legally binding rules. To this end, they distinguish four worlds of compliance in Europe, i.e., clusters of countries that share a common sense of obligation toward implementation duties.

As of now, the empirical evidence is inconclusive, and a number of approaches are available combining elements from each perspective (Knill 2001). However, the above-mentioned approaches may serve as a source of inspiration for those whose research is chiefly concerned with understanding and explaining WFD implementation. We will return to this scholarship when we discuss the use of theory in extant research.

\section{METHODS AND DATA}

This article reviews social science scholarship, published in English-language academic journals, that explores empirically the implementation of the WFD in EU member states. To identify articles matching our criteria, we searched the Web of Science, Science Direct, and Google Scholar databases, using the terms "Water Framework Directive," "WFD," "Integrated Water Resources Management," or "IWRM" in the title, abstract, key words, or topic. We also screened the lists of references of relevant publications and located further work by particular authors through their list of publications. In line with our search criteria, we excluded nonacademic publications such as policy documents and reports prepared by nongovernmental organizations and consultancy firms. Likewise, we did not consider academic research published in book sections, conference papers, and doctoral dissertations, plus otherwise-relevant journal articles published in languages other than English.

We then examined the remaining set of papers and excluded those that did not meet our key search criterion: to report empirically on WFD implementation. This way we discarded articles describing the prehistory (Kaika and Page 2003) and content and ambition (Adshead 2004) of the directive; scholarship offering legal interpretations (Grimeaud 2001) or normative critiques, for instance, as to whether the WFD is compatible with concepts such as Integrated Water Resources Management (Rahaman et al. 2004); and works anticipating rather than studying implementation patterns (Hedelin and Lindh 2008). Among the empirical studies left, we did not consider articles reflecting physical and natural science research (de Toffol et al. 2005), discussing models based on WFD inputs (Crabtree et al. 2009), or studying phenomena not directly linked to the actual implementation of the directive in a member state. These would include, for instance, researcher-led experiments with public participation (Newig et al. 2008) or economic analysis (MartinOrtega 2012), which may have informed WFD implementation but were not part of a country's official implementation schedule. We also excluded articles if the empirical parts were shorter than three pages (Carter 2007).

As a consequence, the findings reported in this article are based on 89 journal articles. See Table 1 .

To analyze the research reported in each source article, we relied on a codebook based on more than 35 items covering author affiliations and countries, research priorities and questions, implementation requirements (for instance, river basin management, public participation, or economic analysis), and levels of analysis (national, RBD, or catchment), as well as the ambition of a study (descriptive, causal, or evaluative) and related theoretical and methodological choices. These items were chosen so as to draw a complete picture of the thematic, geographic, and temporal scales of the research undertaken so far. Because of the small sample size, we do not go beyond basic statistics when we present our findings. Appendix 1 provides a complete list of our codebook items.

We then used categorical, dichotomous, and ordinal variables to code our findings; manually written comments served to justify decisions and to provide additional material for the subsequent analysis and interpretation. The two authors of this article coded, independently from each other, all 89 source papers and resolved disagreements through deliberation.

\section{PUBLICATION PATTERNS: WHO PUBLISHES WHEN AND WHERE?}

We examined 89 journal articles studying, from various disciplinary, theoretical and methodological angles, WFD implementation in Europe. The number as such is impressive. Academic scholarship on the directive is booming, probably being the most-widely studied EU directive, and definitely the mostwidely studied piece of EU legislation in the field of environment. However, those 89 studies have not been published evenly across the years. The academic community began to pay attention to the empirical study of WFD implementation more systematically in 2007 , followed by a remarkable increase in publications after 2010 (Fig. 1). In fact, more than $66 \%$ of all articles were published in the last five years. Furthermore, we are aware of more manuscripts being under way; in other words, the trend is likely to continue.

Fig. 1. Number of publications over time.

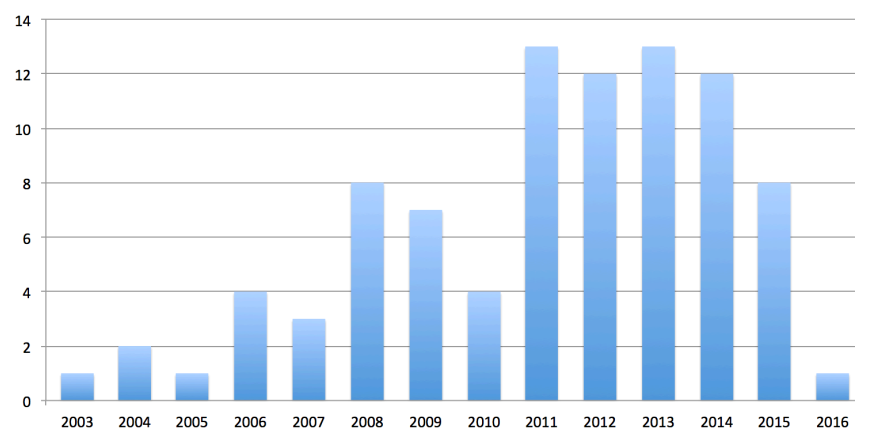

Not surprisingly, those figures reflect WFD implementation patterns in many EU member states. In compliance with EU legislation, many countries had transposed the directive into national law by 2003 before defining RBDs, setting up the necessary institutions and characterizing water bodies. Early research largely reflects those priorities, mainly focusing on the establishment of RBDs (Moss 2004), the characterization process (Kirk et al. 2007), or pilot projects carried out in the context of the Common Implementation Strategy (Carter and Howe 2006, Watson and Howe 2006). However, as we will show further below, it is mainly the institutional novelties in the directive that intrigued the scholarly community, in particular the involvement of nonstate actors in water planning and river basin management. Obviously, those processes could only be described, theorized, and evaluated when they were already under way, i.e., when River 
Table 1. Our sample.

\begin{tabular}{|c|c|c|}
\hline Source articles considered & Countries studied & Key themes \\
\hline Adshead 2006 & Germany, United Kingdom & Participation \\
\hline Albrecht 2013 & Germany & Planning process \\
\hline Allan 2012 & United Kingdom & Ecological status and goals, Planning process \\
\hline Andersson et al. 2012 & Sweden & Planning process \\
\hline Baaner 2011 & Denmark, Sweden & Planning process \\
\hline Behagel and Arts 2014 & Netherlands & Participation \\
\hline Behagel and Turnhout 2011 & Netherlands & Participation \\
\hline Benson et al. 2014 & United Kingdom & Participation \\
\hline Beunen et al. 2009 & Netherlands & Policy integration \\
\hline Bithas et al. 2014 & Greece & Economic analysis \\
\hline Blackstock et al. 2009 & United Kingdom & Policy integration \\
\hline Blackstock et al. 2012 & United Kingdom & Participation \\
\hline Blackstock et al. 2014 & United Kingdom & Participation \\
\hline Blackstock 2009 & United Kingdom & $\begin{array}{l}\text { Ecological goals and status, Participation, Policy } \\
\text { integration }\end{array}$ \\
\hline Borowski et al. 2008 & Germany & Participation \\
\hline Bourblanc et al. 2013 & $\begin{array}{l}\text { Denmark, France, Netherlands, } \\
\text { United Kingdom }\end{array}$ & $\begin{array}{l}\text { Ecological status and goals, Public participation, } \\
\text { River basin management }\end{array}$ \\
\hline Carter and Howe 2006 & United Kingdom & Participation \\
\hline De Stefano et al. 2013 & $\begin{array}{l}\text { Austria, Belgium, Bulgaria, Estonia, } \\
\text { Finland, France, Greece, Hungary, } \\
\text { Ireland, Italy, Latvia, Poland, } \\
\text { Portugal, Slovakia, Spain, Sweden, } \\
\text { United Kingdom }\end{array}$ & Ecological goals and status \\
\hline Dehnhardt 2013 & Germany & Economic analysis \\
\hline Dehnhardt 2014 & Germany & Economic analysis \\
\hline Demetropoulou et al. 2010 & Greece & Participation \\
\hline Dieperink et al. 2012 & Netherlands & Ecological goals and status \\
\hline Drazkiewicz et al. 2015 & Germany & Participation \\
\hline Earle and Blacklocke 2008 & Ireland & Ecological goals and status \\
\hline Estrela 2011 & Spain & Planning process \\
\hline Feuillette et al. 2016 & France & Economic analysis \\
\hline Flynn and Kröger 2003 & Ireland & Participation, River basin management \\
\hline Franzén et al. 2015 & Sweden & Participation \\
\hline Fritsch and Benson 2013 & United Kingdom & Participation, River basin management \\
\hline Gómez-Limón and Martin-Ortega 2013 & Spain & Economic analysis \\
\hline Gooch and Baggett 2013 & Sweden & Participation, River basin management \\
\hline Hammer et al. 2011 & Sweden & Planning process \\
\hline Hanley and Black 2006 & United Kingdom & Economic analysis \\
\hline Hernández-Mora and Ballester 2011 & Spain & Participation \\
\hline Hophmayer-Tokich and Krozer 2008 & Germany, United Kingdom & Participation \\
\hline Howarth 2009 & United Kingdom & Ecological status and goals, Participation \\
\hline Hüesker and Moss 2015 & Germany & River basin management \\
\hline Ioris 2012 & Portugal & WFD in general \\
\hline Ioris 2015 & Portugal & WFD in general \\
\hline Irvine and O'Brien 2009 & Ireland & Participation \\
\hline Jonsson 2005 & Sweden & Participation \\
\hline Junier and Mostert 2012 & Netherlands & Planning process, River basin management \\
\hline Kanakoudis and Tsitsifli 2010 & EU27 & WFD in general \\
\hline Kanakoudis et al. 2015 & EU27, Greece & Planning process \\
\hline Kastens and Newig 2007 & Germany & Ecological status and goals, Participation \\
\hline Kastens and Newig 2008 & Germany & Participation \\
\hline Keessen et al. 2010 & $\begin{array}{l}\text { Belgium, Denmark, France, } \\
\text { Germany, Italy, Luxembourg, } \\
\text { Netherlands, Portugal, Romania, } \\
\text { Spain, United Kingdom }\end{array}$ & Ecological status and goals, Policy integration \\
\hline Keskitalo and Pettersson 2012 & Sweden & Policy integration \\
\hline Kirk et al. 2007 & United Kingdom & Planning process \\
\hline Koontz and Newig 2014a & Germany & Participation \\
\hline Koontz and Newig 2014e $b$ & Germany & Participation \\
\hline
\end{tabular}


Kouw 2014

Kowalczak et al. 2013

Larsen 2011

Laurenceau et al. 2009

Liefferink et al. 2011

Lundmark and Jonsson 2014

Lundqvist 2004

Maganda 2013

Medd and Marvin 2007

Meyer and Thiel 2012

Moren-Abat and Rodriguez-Roldan 2012

Moss 2004

Moss 2008

Moss 2012

Mylopoulos and Kolokytha 2008

Neef 2008

Newson 2011

Nielsen et al. 2013

Parés 2011

Parés et al. 2015

Raadgever et al. 2011

Richter et al. 2013

Slavíková and Jílková 2011

Spiller et al. 2012

Thaler et al. 2014

Theesfeld and Schleyer 2013

Thiel and Egerton 2011

Thiel 2014

Thiel 2015

van der Arend and Behagel 2011

van der Heijden et al. 2014

van der Heijden and ten Heuvelhof 2012

van der Heijden and ten Heuvelhof 2013

van der Veeren 2010

Watson et al. 2009

Watson and Howe 2006

Waylen et al. 2015

Woods 2008
Netherlands

Czech Republic, Poland

Denmark

Belgium, France, Netherlands

Denmark, France, Netherlands

Sweden

Sweden

Luxembourg

United Kingdom

Germany

Spain

Germany

United Kingdom

Germany

Greece

Germany

United Kingdom

Denmark, Finland, Latvia,

Lithuania, Poland, Sweden

Spain

Spain

Netherlands

Germany

Czech Republic

United Kingdom

Belgium, Finland, France, Italy,

Spain, Sweden, United Kingdom

Germany

Portugal

Spain

Germany, Portugal, Spain

Netherlands

Netherlands

Netherlands

Netherlands

Netherlands

United Kingdom

United Kingdom

United Kingdom

United Kingdom
Participation

Participation

Policy integration

Economic analysis

Ecological status and goals, Participation, Policy

integration, River basin management

Participation

Ecological status and goals, Participation

Participation, River basin management

Planning process

Participation, Planning process

Ecological status and goals, River basin management

River basin management

Ecological status and goals

River basin management

River basin management

Participation

Participation

River basin management

Participation

Participation

Planning process

Ecological status and goals

Participation

WFD in general

Economic analysis

Participation, River basin management

River basin management

River basin management

River basin management

Participation

Participation

Participation

Participation, River basin management

Economic analysis

Participation

Participation

Participation

Participation

WFD indicates Water Framework Directive.

Basin Management Plans were adopted in 2009-2010. Consequently, studies analyzing the actual planning process mushroomed in 2011, and figures have remained at high levels since.

What do we know about the authors of those studies? We looked into three dimensions: the country of origin of the first author, their professional background, and if the author is an academic, the departmental affiliation. First, we recorded the country of origin for the lead author of each article. Those authors work in institutions in 13 different member states (Fig. 2). Countries in northwestern Europe dominated; in fact, more than $61 \%$ of all studies were first-authored by scholars based in the United Kingdom, Germany, and the Netherlands. Scholars working in the Czech Republic, Denmark, France, Greece, Ireland, Luxembourg, Poland, Spain, Sweden, and outside Europe published the remaining $39 \%$. We were unable to identify publications authored by scholars in the remaining 15 member states. In fairness, we only talk about lead authors here. However, the overall pattern did not look significantly different when we took into account all authors of a submission; the figures for authors based at institutions in southern and eastern Europe remained significantly low.

Fig. 2. Number of publications by country of origin (first author).

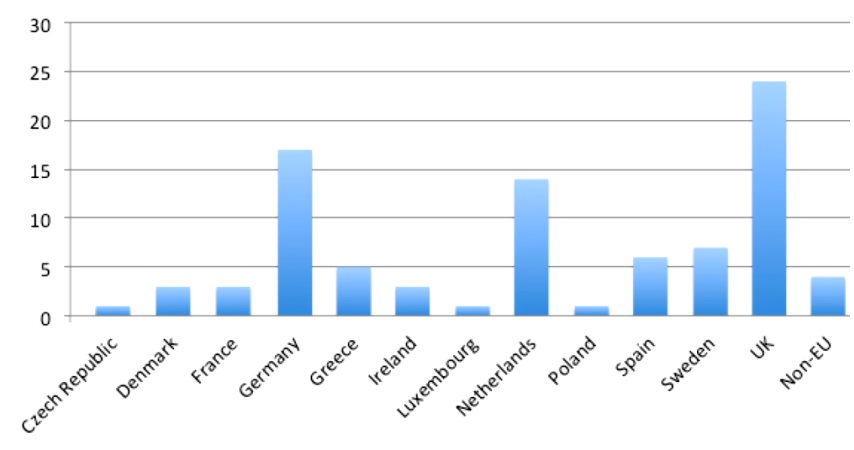


These figures are not counterintuitive. Ultimately, they may simply reflect general patterns of academic productivity. There is no doubt that scholars in southern and eastern Europe carry out high-quality research across the board. Still, academics from northwestern Europe tend to publish in international peerreviewed journals more often than their colleagues in other parts of Europe. We may speculate as to why this is so, but whatever the causes are they say little about WFD research as such. However, it is plausible to argue that the directive is generally more widely studied in the United Kingdom, Germany, and the Netherlands. This may be because the WFD, as a water quality directive, addresses issues of more fundamental importance in northwestern Europe, setting in motion policy makers, civil society, national funding bodies, and the scholarly community. Although troubled by water quality problems too, many regions in southern Europe put a higher premium on the question of water quantity and supply, a preference that may bind scarce research resources. Nevertheless, the observed pattern may have a significant influence on case selection, resulting in a noticeable imbalance as to the countries studied by the WFD community.

Second, a majority of our first authors, some 77 out of 89 articles in the sample, are academics from universities or national research institutes. Ten authors are practitioners, for instance, from government departments, environmental regulators, or charities; two authors have a double affiliation. We were not surprised to see a majority of academics here. Still, we believe that the $11 \%$ nonacademics in our sample is above average, highlighting the importance of WFD-related research for environmental practitioners in Europe. Third, the WFD community in Europe largely consists of scholars working at interdisciplinary environmental social science departments or, in a few cases, at natural science or engineering schools, in total 59 out of 79 in our sample. Only 17 scholars work at social science departments with a clear disciplinary focus: 6 in politics, 5 in law, and 6 in economics. To be clear, this says nothing about their disciplinary background. However, it suggests that many authors operate in an interdisciplinary environment, often with a sympathy for applied research. As we argue below, this is likely to shape theoretical and methodological choices when studying WFD implementation in Europe.

Our analysis of target journals also highlights the interdisciplinary ambition of many scholars. Figure 3 summarizes the Web of Science subject categories of those journals that have published articles in our sample. There are two caveats. First, some journals are listed in several subject categories, so the absolute number of entries is higher than the number of articles in our sample. Second, a few journals are not listed in the Web of Science, and we manually assigned plausible subject categories to those outlets, based on editorial mission statements and other information found on the journal website.

Accordingly, manuscripts about the implementation of the WFD usually find their home in interdisciplinary journals, particularly in those specializing in environmental social science and water resources. Authors rarely target journals in social science subdisciplines such as political science (van der Arend and Behagel 2011, Koontz and Newig 2014a), public administration (Behagel and Arts 2014), economics (Bithas et al. 2014, Dehnhardt 2013), or legal studies (Adshead 2006, Keessen et al.
2010). At first sight, this is somewhat counterintuitive. After all, many authors explore topics such as public participation or the use of cost-benefit analysis in water planning. Arguably, their findings may be of great interest for a wider audience in political science or economics, for instance, for scholars working on deliberative democracy or evidence-based policy making. However, the approaches taken to study such phenomena, specifically the interdisciplinary and often applied nature of WFD-related research, make such work less appropriate for narrow disciplinary debates and more suitable for an interdisciplinary audience and their journals. Still, we are somewhat concerned that scholarly communities may talk past each other; in other words, interdisciplinary outlets may have become another niche for a community of experts rather than an arena of exchange across disciplines. Two journals have become particularly important for scholars specializing in European water management: Land Use Policy, with 11 out of 89 articles in our sample, and Environmental Policy \& Governance (including its predecessor European Environment) with 10 articles. Local Environment, Water Policy and the International Journal of Water Governance constitute another group of preferred target journals.

Fig. 3. Number of publications by Web of Science subject categories.

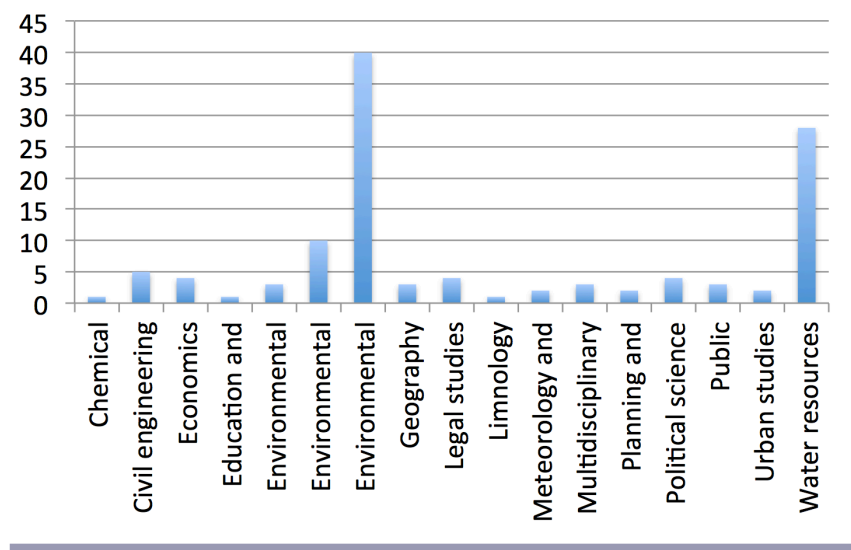

\section{MAPPING SCHOLARLY INTEREST: COUNTRIES, POLICY LEVELS, THEMES}

Now that we have established who publishes when and where, let us take a closer look at the object of those studies: the what. To this end, we organized our review around five dimensions: countries, policy levels, transboundary water management, the temporal stage of WFD implementation, and if the directive has not been studied in its entirety, the aspects of the directive that attracted scholarly attention. In other words, we map scholarly interest across a range of spatial, temporal, and substantial dimensions.

We begin with dimension one, i.e., countries studied. Figure 4 displays the number of publications per country. The absolute number of entries is higher than the number of articles in our sample; this is because some papers report on more than one country. Generally, our sample is characterized by an unhealthy imbalance. Five countries were studied quite thoroughly in the past: the United Kingdom (24 studies), Germany (19 studies), the 
Fig. 4. Number of studies per case study country.

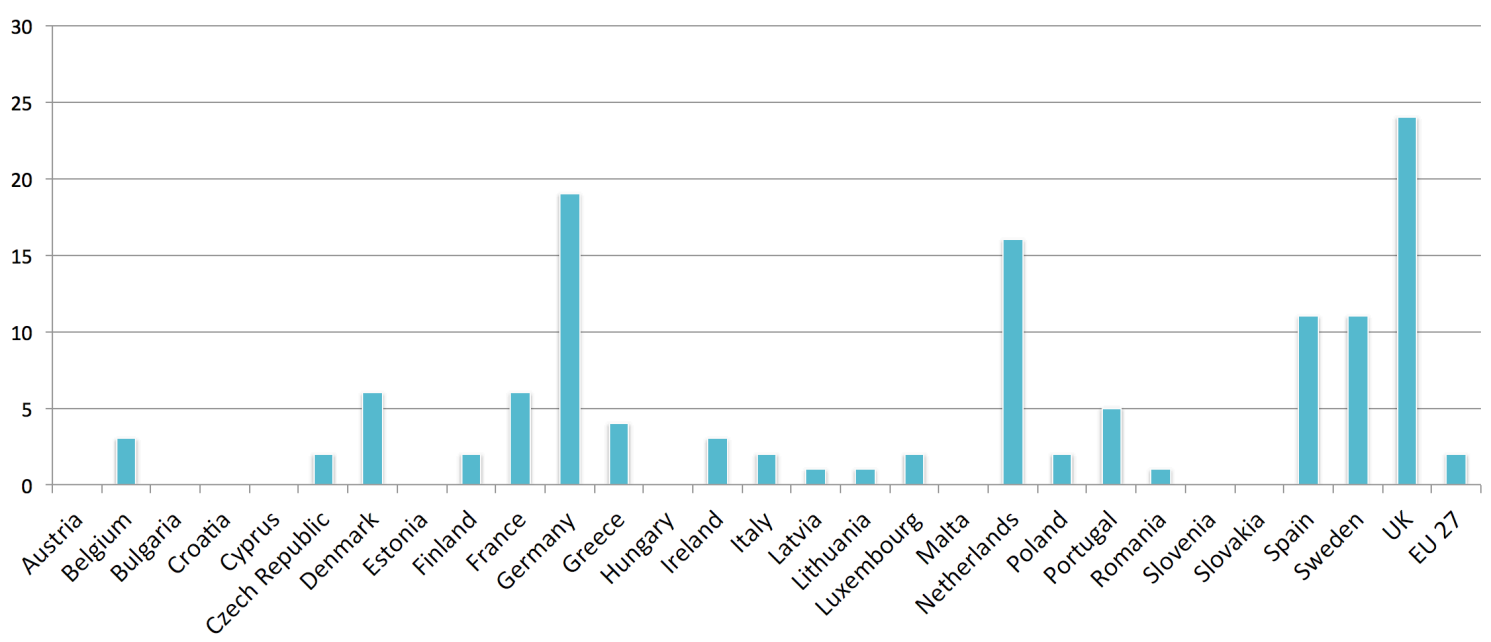

Netherlands (16 studies), and Spain and Sweden (11 studies each). Another group of countries is covered by between three to six articles, including Belgium, Denmark, France, Greece, Ireland, and Portugal. However, a majority of EU member states have received little or no scholarly attention at all. These include many countries that have joined the EU in 2004 or thereafter, for instance, Hungary, Romania, and Slovakia, but also the Baltic states. What should be clear from this brief survey is that much is known about WFD implementation in northern and western Europe, but relatively little about WFD implementation in Mediterranean countries, including founding members and heavyweights such as France and Italy, and in eastern Europe.

We offer two explanations. On the one hand, the above pattern simply reflects patterns of authorship. We have in our sample, for various reasons, a higher number of scholars based at British, Dutch, and German institutions, and this may influence case selection. There are good reasons for that: they speak the language, they have the contacts, they know the context, and they respond to requirements of national funding bodies. On the other hand, there may be an enlargement effect: the 2004, 2007, and 2013 accessions came with important transitory provisions and may have delayed WFD implementation in those countries.

Is all this a problem? Yes and no at the same time. Case selection is not random. Academics choose cases to make a specific argument, to test an established theoretical proposition, or to develop a new one. This argument may result in a specific interpretation or critique that remains valid and plausible beyond the case studied. Scholars in our sample sometimes study the WFD, or specific provisions of the directive, to make a claim that is entirely decoupled from the directive. For instance, Drazkiewicz et al. (2015) used WFD cases to test the hypothesis that participatory arrangements enhance the ecological quality of environmental decisions and their implementation. There is little reason to study Austria, Bulgaria, or Malta if there was no participation in those countries that could have had an effect on environmental outcomes. However, as we show further below, when we talk about research design choices, an overwhelming majority of studies in our sample are descriptive, sometimes with evaluative undertones. Authors report what is going on and sometimes use ad hoc or theory-informed benchmarks to assess what they observe, often, so it seems, with a view to supporting the implementation of WFD provisions in their country. From this perspective, the above-mentioned imbalance is unfortunate because it provides an incomplete picture. This is no trivial observation: many evaluations suggest that WFD provisions were implemented in an incomplete or suboptimal way. That may be true or not, but it would certainly be helpful to put such assessments into context by studying countries whose implementation record is, if we trust EU reports and media coverage, less than ideal too. In other words, selective cases may highlight deficits that are negligible if compared against other cases and may direct our attention away from more serious problems.

We now turn to dimension two: the policy level studied. We distinguish three levels: the national level, relevant for the domestic transposition of the WFD and sometimes for the general organization of WFD water planning in a EU member state; the RBD level, i.e., the reference level envisaged in the directive for the preparation of management plans; and the sub-RBD level, in this article conveniently called the catchment level, although we do not associate any specific ecological definition to this term. Table 2 below summarizes our findings.

Table 2. Number of studies per policy level.

\begin{tabular}{lccc}
\hline \hline Policy level & National & $\begin{array}{c}\text { River basin } \\
\text { district }\end{array}$ & Catchment \\
\hline $\begin{array}{l}\text { Number of studies } \\
\text { considering this level }\end{array}$ & 14 & 17 & 12 \\
$\begin{array}{l}\text { Number of studies studying } \\
\text { only this level }\end{array}$ & 30 & 16 & 25 \\
\hline
\end{tabular}

Accordingly, we have 30 articles in our sample that strictly analyze the national level. These are followed by research looking into processes at catchment level. There is a relatively low number of 16 articles studying the WFD at the RBD level. A further set of 
18 articles study combinations of, and sometimes the interactions between, several levels. We were surprised about the minor importance of RBDs and the larger number of studies focusing on catchments, given the prominence of RBDs in the directive. We offer three explanations. First, some member states may have found the RBD level somewhat impractical and organized important management activities at lower levels instead. This may be the case when RBDs conflict with administrative boundaries in a federal system such as Germany, where important planning activities are carried out at catchment level (Koontz and Newig 2014b). Obviously, this may direct scholarly attention away from RBDs. Second, some RBDs are inconveniently large to be studied in-depth through qualitative methods. In other words, the study of catchments is a methodological choice although, as we will argue below, such choices have not always been made explicit. Third, when the actual policy level does not matter, scholars go where the data are. For instance, when Borowski et al. (2008) decided to study the effects of participatory arrangements on social learning, they chose the level where such involvement processes take place. Case selection follows theory. Still, in light of the fact that many studies in this field have no causal ambition and remain descriptive, it is fair to argue that such descriptions then tend to show an incomplete picture. Incomplete in the sense that the reader does not always know how representative a catchment is vis-à-vis other catchments. Furthermore, extensive knowledge about one particular policy level does not necessarily enhance our knowledge of other levels and their interactions. For instance, we possess an in-depth understanding of German WFD water planning at the catchment level and of important initiatives at the federal level. However, despite a wealth of publications on Germany we are still in the dark as to the coordinative mechanisms between federal states, i.e., mechanisms in place to integrate river basin planning and catchment level activities in various states. Future research will definitely benefit from perspectives that integrate various policy levels to provide a more complete picture of WFD water planning.

Dimension three looks into the transboundary aspect of river basin management. Almost all countries in continental Europe share at least one river basin with their neighbors. So far, no powerful mechanisms are in place to encourage river basin management beyond national borders. International commissions exist for each transboundary basin, but important parts of the planning process are excluded from such coordination, not least because countries implemented WFD provisions at a very different pace. At the time of writing, the scholarly community has not taken many steps to look into the transboundary aspect of WFD implementation. We have 33 studies studying RBDs, a vast majority of those RBDs being transboundary, but only one study (Mylopoulos and Kolokytha 2008) addresses this issue by studying both sides of a Greek-Bulgarian basin. All other studies remain on "their" side of the river; Meyer and Thiel (2012), for instance, study the German part of the Odra basin and ignore the Polish part. Likewise, the largest river basin in Europe, the Danube, has been managed for more than 150 years in the spirit of transboundary water management, through various international commissions established by international agreements. However, this has rarely attracted scholarly attention, and never in a WFD context. We believe this is a fundamental research gap. We acknowledge that there are limits to such a research program, exactly because river basin management beyond national borders currently meets various political, administrative, and perhaps, ideological obstacles. Still, scholarship on WFD implementation would greatly benefit from studies establishing the presence or absence of transboundary mechanisms.

We now move from spatial and scalar aspects to the temporal dimension of implementing the directive. This is dimension four: What stages of the WFD planning process have been studied so far? Member states were supposed to implement the directive in various steps. This involves transposing the WFD into national law, identifying RBDs, nominating a competent authority, designating water bodies, assessing pressures on aquatic environments and evaluating the risk of missing environmental targets (characterization process), and the drafting of River Basin Management Plans and Programmes of Measures. The early stages of the implementation process were accompanied by pilot measures. They were carried out in the context of the common strategy of implementation with a view to supporting the implementation of "tricky measures," such as the involvement of nonstate actors or the use of economic analysis in water planning.

Our sample includes three articles that analyze pilot projects: two of them on participation and one on cost-benefit analysis. All three report on the United Kingdom. Nine papers address, among other issues, the process of transposing the WFD into national law. A vast majority of papers in our sample, 86 out of 89 , cover the preparation phase from 2003 to 2009 (and in some countries, 2010). This is not very counterintuitive per se. After all, many exciting innovations, from a social science perspective, could be observed only during or after the preparation phase. These include the establishment of RBDs, the involvement of stakeholders in the planning process, and the application of various economic decision-making tools. However, there is a caveat here: Many studies provide a snapshot, i.e., report about a specific moment in time or a particular step in implementing the directive. A few studies present a bigger picture or compare WFD implementation efforts over time. For example, we identified only three articles explicitly studying the first implementation cycle from 2009 to 2015 or systematically comparing the experience gained in different sectors and countries in the preparation phase and the first cycle.

Finally, in dimension five, we analyzed the various themes and requirements, usually institutional innovations, that can be found in the WFD and that may have attracted scholarly attention. We distinguished seven themes: the ecological goals of the directive and how achievement of those goals has been encouraged or enforced in EU member states, including the designation of water bodies; the use of economic principles as reflected in tools such as cost-benefit analysis in water planning; the establishment of RBDs and problems that arise as a consequence of rescaling; the involvement of nonstate actors in water planning; the integration of other policy areas in WFD water management, for instance, climate, forestry, flooding, and biodiversity; the planning process, if not specifically focused on participation, economic tools, policy integration, or river basin management; and a residual category: WFD in general. This last category is particularly useful for studies looking into the overall transposition of the directive into national law. However, the category also covers quantitative 
research aggregating several WFD themes across a large number of EU member states such that important lessons can be drawn regarding the general implementation of the directive in Europe, although at the same time, because of the step of aggregating information, little can be said in detail about, for example, participation, economic analysis, or policy integration. Figure 5 below reports our findings. Quite a few articles discuss more than one theme; the absolute number of entries is therefore higher than the number of articles in our sample.

Fig. 5. Number of studies per WFD theme. WFD indicates Water Framework Directive.

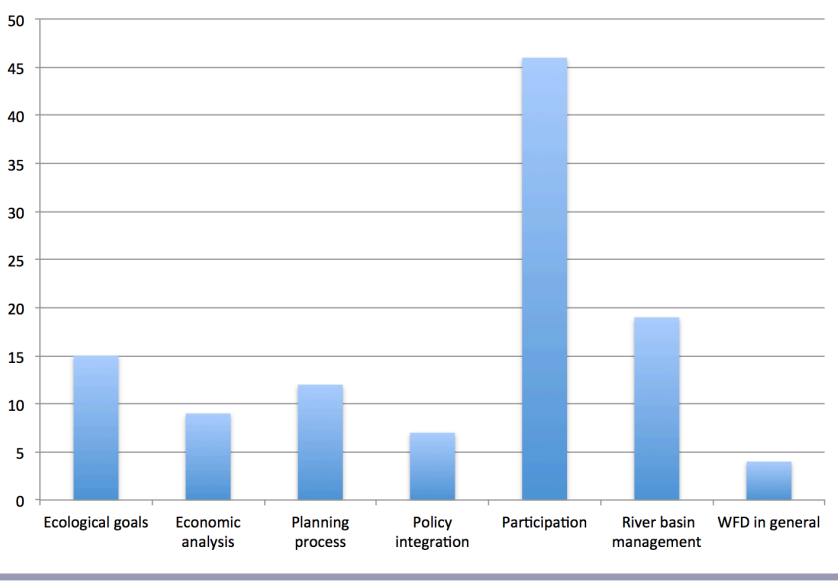

What do the data tell us? We observed a great imbalance as to the institutional novelties promoted by the WFD. The involvement of nonstate actors in water planning has inspired a rich literature. In fact, $52 \%$ of all articles and (the figures differ here because articles often report on more than one theme) $41 \%$ of all themes are related to public participation in WFD water management. To be clear, it is beyond the scope of this article to discuss the achievements made in this field. However, what can be said is that previous work centers on three themes. First, we have a number of publications taking a Europeanization perspective; i.e., they ask why specific domestic arrangements have come into place and what role the EU plays therein (Liefferink et al. 2011). Second, authors explore the effects of participation, typically on social learning processes (Borowski et al. 2008), ecological outcomes and implementation (Drazkiewicz et al. 2015), or legitimacy (Behagel and Turnhout 2011). Third, we found a series of articles comparing instances of participation against legal or normative benchmarks, i.e., evaluative exercises (Watson and Howe 2006, Slavíková and Jílková 2011, Benson et al. 2014). With the exception of works focusing on ecological outcomes, an aspect still treated with neglect, the above questions represent strands of research that speak to a wider and already well-established literature.

Certainly, this enthusiasm for participation within the WFD research community calls for an explanation. We offer three. First, research interviews with national water managers and European Commission officials, carried out in the context of other projects, suggest that of all institutional novelties proposed by the WFD, public participation perhaps represents the greatest challenge to national administrative cultures and established water management traditions. Exploring public and stakeholder engagement therefore constitutes an excellent opportunity to study administrative reform, institutional change, and learning in contested settings. Second, these challenges resulted, in our mind, in an exceptionally high number of funded projects at national and EU levels, consultancy opportunities, and other incentives for researchers to collaborate with policy makers and stakeholders on participation. Third, participation resonates with a wide variety of literature, much more than other institutional novelties in the directive do. This includes communities working on EU policy implementation, on participatory and deliberative democracy, on regulatory reform, on policy effectiveness of participatory governance, on social learning, and many others.

We found less work, $20 \%$ of all articles, on water management at ecological scales. Once again, scholars study questions related to the Europeanization of domestic arrangements, i.e., of policy implementation. When authors identify misfits between EU requirements and domestic practice, and in this context this means between ecological and administrative scales, a link is usually made to the literature on spatial fit and institutional interplay (Moss 2004, 2012). This literature is even more prominent in works investigating economic rationales for specific scalar arrangements (Thiel and Egerton 2011, Thiel 2014).

However, regulatory tools such as cost-benefit analysis remain understudied (but see Dehnhardt 2013, 2014). In other words, scholarship investigating the identification of environmental benefits and costs, approaches toward cost recovery of water services and incentive pricing, and the link between participation and economic analysis, in particular how they complement each other, is still in great demand. We also believe that the politics of exemptions is neglected so far, i.e., political strategies that often result in less stringent water quality objectives. Finally, policy integration is rarely considered in prior work, in particular with regard to climate policy - our sample includes two articles that exclusively analyze this relationship in Denmark and Scotland (Blackstock 2009, Larsen 2011) — and to EU policies based on similar management philosophies. These include, for instance, the Birds and Habitats Directives, the Marine Strategy Framework Directive, and the Floods Directive; we hypothesise they could be a source of both mutual reinforcement and conflict (Beunen et al. 2009). In fairness, the literature on institutional interplay (Young 2002; in a WFD context see, e.g., Moss 2004, Newig and Fritsch 2009, Hüesker and Moss 2015) has addressed such questions. However, we still see the promise of linking spatial approaches to the integration of different policy fields in WFD research more than in the past.

\section{STUDYING WFD IMPLEMENTATION: THEORY AND METHODS}

In this section we discuss how previous scholarship has approached the study of WFD implementation. To this end, we focus on three aspects. The first is the ambition of the research project; we hereby distinguish descriptive, causal, and evaluative work. The second is questions of research design and methodology. The third is choices made in terms of concepts and theory.

In terms of ambition, we identified three ideal types: (1) papers with a causal ambition that try, supported by theory and conceptual frameworks, to establish a causal link between two or 
Fig. 6. Research ambition across Web of Science subject categories.

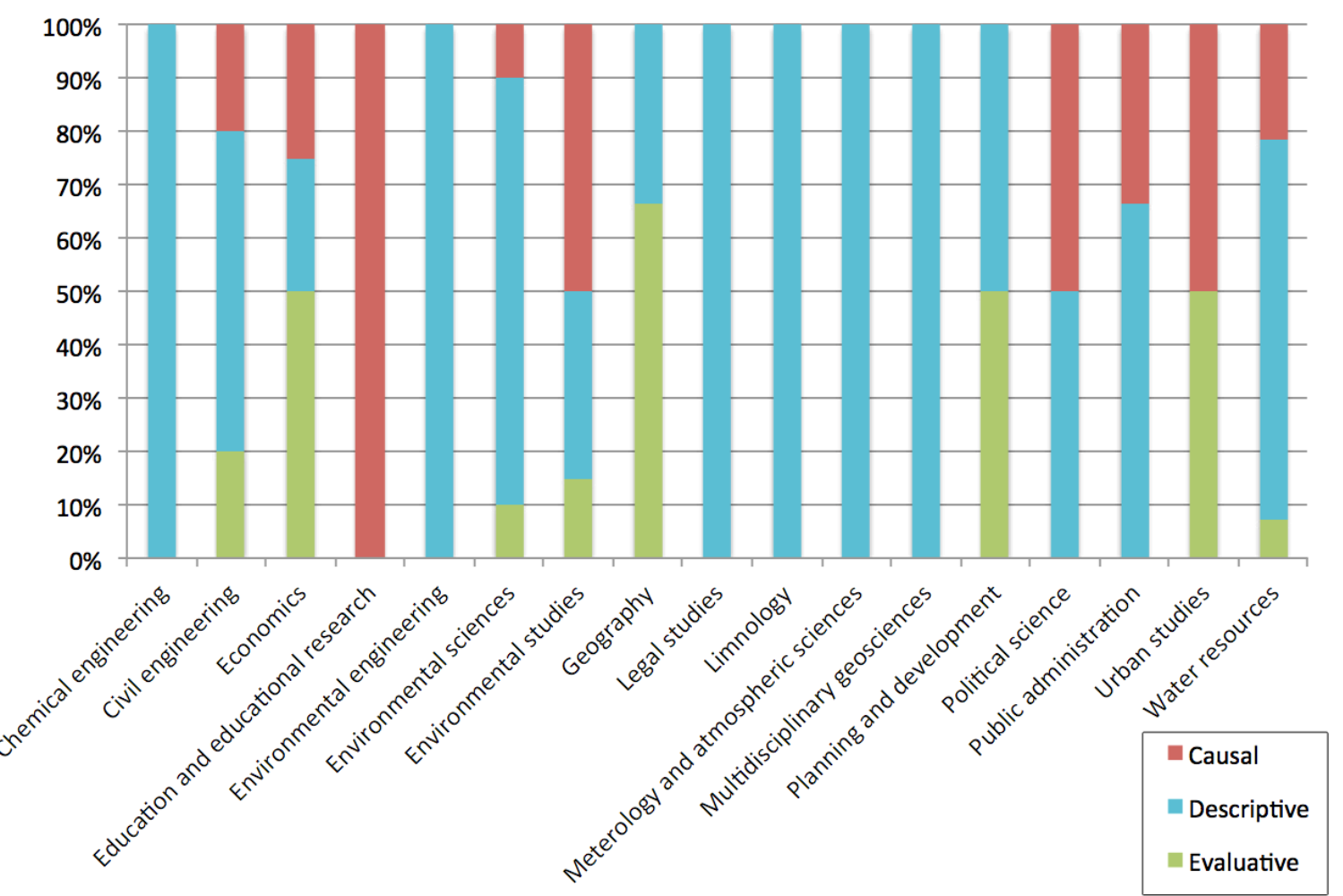

more independent and dependent variables; (2) evaluative papers that compare patterns of WFD implementation against legal requirements or normative frameworks; and (3) descriptive papers that portray and detail a phenomenon without embedding it in an explanatory or normative framework. We complemented those ideal types with two additional categories: causal papers without theory, i.e., based on ad hoc explanations; and evaluative papers without normative framework, i.e., providing ad hoc evaluations.

We observed a large number of descriptive work in our sample. About $55 \%$ of all articles, 49 out of 89 , describe the implementation of the directive, or of a specific WFD theme, in Europe. However, those authors do not use their empirical material to build, explore, or test theories or to appraise their subject of analysis using a normative framework. Furthermore, 13 articles in our sample are descriptive in nature, but come with ad hoc causal explanations. Likewise, 3 papers present ad hoc evaluations. Only 18 articles display a distinct causal ambition, relying on theory and hypotheses, and 6 papers offer a normative critique based on a previously defined framework against which authors compare their observations. In other words, only $24 \%$ of all articles go beyond descriptive or ad hoc ambitions.

According to our data, journal articles display a descriptive research interest more often if they appear in physical science, engineering, or interdisciplinary journals. Figure 6 below summarizes the type of ambition across the Web of Science journal subject categories in which the journals in our sample are listed.
Our sample of 89 articles includes quite a few articles published in physical science journals or outlets with a technical orientation, i.e., in journals belonging to Web of Science subject categories such as chemical engineering, civil engineering, environmental sciences, limnology, or metereology. Figure 6 suggests that those journals have a particularly strong preference for descriptive submissions. The picture is mixed with regard to interdisciplinary journals. We have many descriptive pieces in periodicals specializing in water resources, whereas the environmental Studies category is more balanced. Finally, journals in classic social science subdisciplines such as economics, political science, or public administration as well as in geography and urban studies tend to publish more research with causal or evaluative ambitions. Our analyses also suggest that practitioners are more likely to publish descriptive work, and they prefer to do so in physical science, engineering, or interdisciplinary journals.

All studies with an evaluative ambition have one thing in common: They focus on public participation, including research on Ireland (Irvine and O’Brien 2009), the Czech Republic (Slavíková and Jílková 2011), Spain (Parés 2011), and the United Kingdom (Blackstock et al. 2012, Fritsch and Benson 2013, Benson et al. 2014). None of those countries had well-established participatory mechanisms in place prior to the adoption of the directive. It is therefore not surprising to see authors evaluating the progress made after the WFD was transposed into national law.

We observed more heterogeneity when we looked at causal projects in our sample. Articles cover areas as diverse as public participation, river basin management, and economic analysis, 
but also the directive as a whole. The majority of articles use WFD implementation as the dependent variable; i.e., they try to shed light on the political, economic, or societal causes of specific implementation patterns. To this end, authors either refer to the Europeanization literature (Liefferink et al. 2011, Moss 2004) or use public policy approaches, including institutional theories (Thiel and Egerton 2011, Nielsen et al. 2013, Thiel 2014), policy change models (Bourblanc et al. 2013), and the advocacy coalition framework (Dehnhardt 2014). Another set of work uses WFD implementation as the independent variable. Such studies explore, for instance, the effects of participatory exercises whereby social learning (Borowski et al. 2008, Lundmark and Jonsson 2014) or policy implementation and environmental outcomes (Koontz and Newig 2014a; Drazkiewicz et al. 2015) constitute the dependent variables.

The Europeanization literature has developed a number of fruitful approaches to explain EU policy implementation. We distinguished earlier the goodness-of-fit, actor-based, and worlds-of-compliance approaches, plus theories combining the goodness-of-fit approach with additional variables. The WFD community has, to date, made only limited use of this literature. In fairness, this may be because authors never meant to explain implementation patterns in the first place; instead, they may have selected the directive as an independent variable. However, only two papers in our sample analyze the implementation of the WFD as dependent variable and utilize the Europeanization literature systematically (Liefferink et al. 2011, Moss 2004); both papers employ a variant of the goodness-of-fit approach with additional variables. Although Albrecht (2013) mentions the term "Europeanization" in the title of her paper, no further reference to this literature is made in the remainder of the article. There is certainly potential to employ a wider array of approaches in a WFD context, ideally in a comparative setting with competing theories.

The overall dominance of descriptive projects in this literature is, in our estimation, problematic. To be clear, we recognize that explanation and evaluation are not necessarily key priorities for many authors studying the WFD. We also appreciate the fact that many interdisciplinary scholars seek impact outside rather than inside the academy. Finally, we agree that "mere description" (Gerring 2012) has its merits. To illustrate, descriptive research may constitute a springboard for subsequent evaluative or causal projects, including meta-analyses and comparative studies. Unfortunately, however, empirical documentation of such uses in a WFD context is minimal. So far we are left with a pile of articles that describe in more or less detail important features of WFD implementation in Europe. However, we as readers are somewhat left in the dark as to what the purpose, mission, or function of those articles is. After all, their observations cannot easily be translated across cases or disciplines; these articles often contain rich materials shy of a research question. To enhance the echo of such research beyond the community of WFD scholars, we think authors are well advised to carry the empirical torch slightly farther than to the nearest descriptive pit stop.

This is where theory kicks in. Essentially, WFD implementation research is theory-free territory. Almost 50 articles out of 89 do not mention theory at all. Others mention concepts and theories in between the empirical material, but those references do not really enhance our understanding of the overall argument; name dropping seems to outplay systematic utilization. There are a small number of theory-guided studies in our sample where conceptual considerations inform hypothesis building or normative frameworks. However, by and large, theory falls by the wayside. This is a direct corollary of the descriptive or ad hoc direction taken by many studies. If somebody prioritizes description or is content with ad hoc conclusions, there is little necessity for abstract reasoning. We find this lack of theory stunning. Theories are extremely useful vehicles to translate ideas across cases and disciplines, and we are convinced that the WFD community would benefit from a more systematic recourse to concepts, hypotheses, systematic classifications, and theory.

In terms of methodology, the WFD implementation literature is still in its infancy. We initially planned to map methodological choices made in this literature against classic approaches in social science. However, we failed to do so: More than $30 \%, 27$ out of 89 articles in our sample, provide virtually no information on research design, methods, and data. We can sometimes infer from the list of references that policy documents have informed the analysis; we may make the educated guess that some conclusions must be based on interview data or direct observation. However, the sheer absence of any methodological statement in almost one third of all publications casts a shadow over the entire subfield. Transparency and openness with regard to data sources and analysis are prerequisites for critical debate and enable the confirmation and refutation of claims. It is a professional standard that should not be given up lightly, and we do not see the merits of downplaying methodological precision. According to our data, authors operating in physical science or engineering schools are more likely to take a relaxed approach to methodology when they report on WFD implementation; likewise, such articles tend to be published in natural science or engineering journals.

Another set of 18 articles report on data and research design. However, this information does not form a coherent methodological section, but is presented as part of the introduction, in the empirical sections, or simply in a footnote. The average word count is 138; in 9 papers it is 75 words or fewer, which is, upon sober reflection, definitely insufficient to inform adequately about the methodological choices made. Finally, 44 out of 89 articles, fewer than half of the sample, provide a separate section dedicated to data and methods, with an average length of 579 words. Those studies usually rely on qualitative methods, particularly interview data, policy documents, participatory observation, and media analyses. Because of the overall lack of theory, there is little dialogue between theory and methods. In other words, methodological choices are rarely motivated by theory. Consequently, justifications for specific research designs and data analysis methods are very practical in nature.

With regard to research design, our sample looks very uniform. First, our knowledge about WFD implementation in Europe primarily relies on single case studies or small-n comparisons within one country. Our sample includes 74 single country studies, 2 comparisons between EU countries and jurisdictions overseas, as well as 11 comparative studies within Europe (between 2 and 11 countries each). There is a striking lack of large-n quantitative research: We only identified 2 studies (Kanakoudis and Tsitsifli 2010, Kanakoudis et al. 2015). Second, those 11 small-n studies 
are not always comparative in methodological terms. This is because they frequently fail to sort cases into comparable sets, and cases are rarely chosen because of their properties. In other words, there are few attempts to use only most-similar, mostdifferent, or related strategies so as to maximize the benefits of a comparative research design. In this sense, many multicountry studies resemble case collections rather than theoretically and methodologically justified case comparisons. Not surprisingly then, 6 of those 11 studies are descriptive; 4 others have a causal ambition, and the remaining study offers an ad hoc explanation.

We argued before that the WFD community has submitted their research to a diverse range of journals, from economics and political science outlets to interdisciplinary journals and physical science periodicals. We now explore whether publication choices are linked to research ambition and methodological transparency. The underlying intuition is that articles characterized by less ambitious research programs or weaker methodology parts are likely to be published in lower-ranked journals.

We first used the Web of Science to establish the relative position of a journal in its respective subject category ranking, based on the two-year impact factor at the time of publication of each article in our sample. To this end, we classified those journals as belonging to one of the following seven categories: top 5\%, top $10 \%$, top $25 \%$, top $50 \%$, top $75 \%$, or top $100 \%$ of its respective Web of Science journal subject category; journals not listed at all form the last category. This way we are able to compare journals across Web of Science subject categories, although those categories differ as to their average impact factor and the number of journals listed. In other words, we argue that a journal on position 6 in a subject category with 138 journals enjoys, within its disciplinary community, a greater reputation than a journal on position 4 in a subject category of 59 journals. If a journal was listed in several categories, we used the best measure of this journal. The approach also enabled us to control for publication years; i.e., we considered the possibility that journals move up and down in the rankings over time.

We are aware that this approach has limits. On the one hand, we used the publication year of an article although the time of submission would be a more precise measure; this information, however, was not available to us. On the other hand, the position of a journal in a subject category ranking reflects its impact factor, a metric that has attracted widespread criticisms (Giles and Garand 2007, Plümper 2007, Garand et al. 2009, Eyre-Walker and Stoletzki 2013). The impact factor is statistically vulnerable because of the small sample size in many subject categories. Citation patterns often reflect journal availability rather than journal quality; authors cannot use a specific article if their institution provides no access. The impact factor is influenced by self-citations. Finally, the impact factor counts citations, but does not consider whether authors cite papers in a supporting or in a critical fashion. This implies that the impact factor says less about quality and more about reputation. However, we still believe that the relative position of a journal in the rankings provides the most useful metric in the context of this article.

Our findings are straightforward: Although there is no linear trend, our analysis suggests that theory-based causal and evaluative projects are more likely to be published in higherranked journals. Descriptive papers and those relying on ad hoc analyses, in contrast, tend to be published in outlets at the bottom of their subject category ranking or in outlets not listed in the Web of Science at all (Fig. 7). Figure 8 displays the relationship between methodological transparency and position in the rankings.

Fig. 7. Research ambition across journal ranking positions.

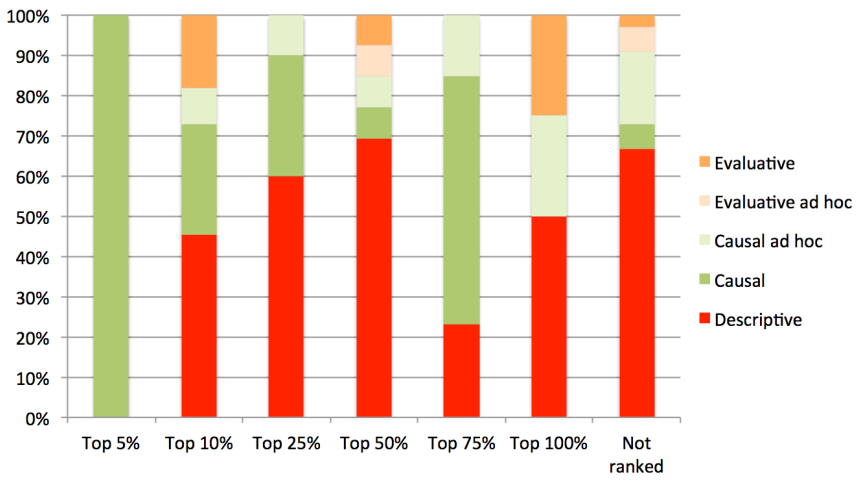

Fig. 8. Methodological transparency across journal ranking positions.

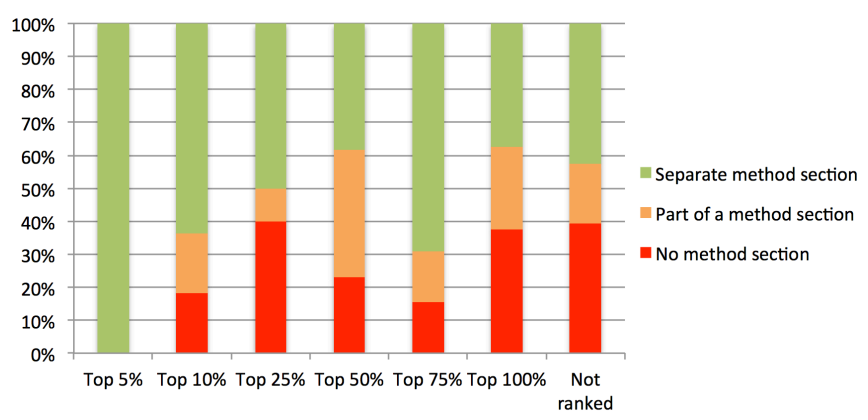

Our findings suggest that, although there is one outlier category at $75 \%$, higher-ranked journals tend to prefer submissions with a separate and, as we have shown earlier, longer methods section. Lower-ranked journals or outlets not listed at all are more likely to publish papers where information on data, cases and research design forms a shorter part of the introduction or empirical section, or papers with no methodological information at all.

\section{CONCLUSION}

We set out to systematically review studies dedicated to the implementation of the WFD in Europe. Based on a meta-analysis of 89 journal articles, we explored more than 35 dimensions in each study to report on authors and journals, countries, policy levels, and WFD themes, as well as on theory, methods, and research design.

Returning to our thought experiment described earlier, Table 3 below displays research priorities with regards to countries and WFD requirements, thereby ignoring the temporal dimension. The chart stresses that quite a few areas of research are well documented, whereas others appear as blind spots. We discuss them in turn below. 
Table 3. Number of studies per country and WFD theme.

\begin{tabular}{|c|c|c|c|c|c|c|c|}
\hline Country & $\begin{array}{c}\text { Ecological } \\
\text { status }\end{array}$ & $\begin{array}{c}\text { Economic } \\
\text { analysis }\end{array}$ & Planning process & $\begin{array}{c}\text { Policy } \\
\text { integration }\end{array}$ & Participation & $\begin{array}{l}\text { River basin } \\
\text { management }\end{array}$ & WFD in general \\
\hline Belgium & 1 & 2 & 0 & 1 & 0 & 0 & 0 \\
\hline Czech Republic & 0 & 0 & 0 & 0 & 2 & 0 & 0 \\
\hline Denmark & 3 & 0 & 1 & 3 & 2 & 3 & 0 \\
\hline Finland & 0 & 1 & 0 & 0 & 0 & 1 & 0 \\
\hline France & 4 & 3 & 0 & 2 & 2 & 2 & 0 \\
\hline Germany & 3 & 2 & 2 & 1 & 11 & 6 & 0 \\
\hline Greece & 0 & 1 & 1 & 0 & 1 & 1 & 0 \\
\hline Ireland & 1 & 0 & 0 & 0 & 2 & 1 & 0 \\
\hline Italy & 1 & 1 & 0 & 1 & 0 & 0 & 0 \\
\hline Latvia & 0 & 0 & 0 & 0 & 0 & 1 & 0 \\
\hline Lithuania & 0 & 0 & 0 & 0 & 0 & 1 & 0 \\
\hline Luxembourg & 1 & 0 & 0 & 1 & 1 & 1 & 0 \\
\hline Netherlands & 4 & 2 & 2 & 3 & 9 & 4 & 0 \\
\hline Poland & 0 & 0 & 0 & 0 & 1 & 1 & 0 \\
\hline Portugal & 1 & 0 & 0 & 1 & 0 & 2 & 2 \\
\hline Romania & 1 & 0 & 0 & 1 & 0 & 0 & 0 \\
\hline Spain & 3 & 2 & 1 & 1 & 3 & 3 & 0 \\
\hline Sweden & 1 & 1 & 3 & 1 & 5 & 2 & 0 \\
\hline United Kingdom & 6 & 1 & 2 & 2 & 15 & 2 & 0 \\
\hline EU27 & 0 & 0 & 1 & 0 & 0 & 0 & 2 \\
\hline
\end{tabular}

WFD indicates Water Framework Directive.

We found, first, that there is a cluster of very well-researched countries, including the United Kingdom, the Netherlands, and Germany; however, member states that joined the EU in 2004 and 2007 as well as Mediterranean countries such as Italy and Greece are under-represented. These are gaps to be filled. However, we envisage two more promising research programs: On the one hand, we encourage scholars to compare groups of countries. EU policy implementation research talks about 'worlds of compliance' (Falkner et al. 2005), and the WFD would lend itself well to an empirical test of this claim. Furthermore, we believe a more systematic comparison of northern and southern EU member states will help understand the role of water quality and water quantity problems in EU environmental policy implementation. On the other hand, we suggest taking a closer look at candidate states, countries addressed by the European Neighbourhood Policy, and associated countries such as Switzerland and Norway (but see Baaner 2011).

Second, there is a certain imbalance as to the institutional novelties promoted by the WFD. Although the involvement of nonstate actors in water management has inspired a rich literature, there is less in-depth research on river basin planning and management at ecological scales. Most importantly, economic principles, as reflected in tools such as cost-benefit analysis, have not been studied in depth. This includes cost-effectiveness analysis, incentive tarification, adequate levels of cost recovery, and designation of heavily modified water bodies, all of them challenging in terms of knowledge, uncertainty, legitimacy, and social acceptability. The politics of exemptions, which often results in less stringent water quality objectives, also remains understudied. We identified three additional areas for future research. On the one hand, the directive and early guidance documents made no reference to measures supporting adaptation to climate change. However, the topic has become more prominent at the EU level (European Commission 2009b), and we suggest more systematic research exploring the link between WFD management activities and climate change adaptation. On the other hand, EU policy documents increasingly make reference to ecosystem services as a key concept to support WFD implementation (European Commission 2012b). Future research could take the cue and analyze whether, and if so how, this plays out on the ground. Furthermore, we encourage more empirical research on the interaction between the WFD, the Floods Directive, and the Marine Strategy Framework Directive, and with legislation unrelated to water, for instance the Birds and Habitats Directives. Intuitively, we would expect the potential for mutual reinforcement, for instance, when it comes to promoting a culture of participation in environmental management, but also for conflict and contestation in other areas (but see Newig et al. 2014).

Third, there is a lot of research on the preparation phase of WFD implementation, more specifically on the process of drafting the first set of river basin management plans. However, we know little about continuity and change from the preparation phase to the first cycle, and there is little comparative work over time. Further research priorities may include the achievement of the 2015 water quality goals and the role of governance innovations such as participation therein, and comparisons of the preparation phase, the first management cycle, and the on-going second management cycle. The latter may relate to a number of literatures, including those on policy learning and the role of guidelines, training, and capacity building in policy making (May 1992).

Fourth, there is a conspicuous lack of theory in WFD scholarship. Authors tend to describe implementation patterns and, at times, to apply normative frameworks, but only a minority of studies refer to theory when explaining compliance with the WFD and embed observations in their social, economic, or political contexts. In this paper we outline a number of approaches and 
refer to others. All of them may be useful to help explain patterns of WFD implementation. We are convinced that theory deserves a more prominent place in future research on the WFD and its implementation in Europe.

Fifth, methods and research design are patently neglected and a serious cause of concern. Authors accord little attention to methodological questions, and papers mostly have a descriptive orientation. Overall, 21 out of 89 articles are descriptive and provide no information on data and methods. Moreover, our current knowledge about the implementation of the WFD in Europe relies mainly on single case studies or small-n comparative studies within one country. Cross-country comparisons are a minority, and there is a striking lack of large-n quantitative research. We believe future research would benefit from a departure from single-country studies.

Responses to this article can be read online at: http://www.ecologyandsociety.org/issues/responses. $\mathrm{php} / 8411$

\section{Acknowledgments:}

We warmly thank Will Hankey for research assistance.

\section{LITERATURE CITED}

Adshead, J. 2004. River basin management in the Water Framework Directive: an integrated approach to water protection and management. Water Law 15:5-11.

Adshead, J. 2006. Public participation, the Aarhus Convention and the Water Framework Directive. Journal of Water Law 17:185-192.

Albrecht, J. 2013. The Europeanization of water law by the Water Framework Directive: a second chance for water planning in Germany. Land Use Policy 30:381-391. http://dx.doi.org/10.1016/ j.landusepol.2012.04.009

Allan, R. 2012. Water sustainability and the implementation of the Water Framework Directive-a European perspective. Ecohydrology \& Hydrobiology 12:171-178. http://dx.doi. org/10.2478/v10104-012-0007-1

Andersson, I., M. Petersson, and J. Jarsjö. 2012. Impact of the European Water Framework Directive on local-level water management: case study Oxunda catchment, Sweden. Land Use Policy 29:73-82. http://dx.doi.org/10.1016/j.landusepol.2011.05.006

Baaner, L. 2011. Programmes of measures under the Water Framework Directive-a comparative case study. Nordic Environmental Law Journal 1:31-52.

Behagel, J. H., and B. A. S. Arts. 2014. Democratic governance and political rationalities in the implementation of the Water Framework Directive in the Netherlands. Public Administration 92:291-306. http://dx.doi.org/10.1111/padm.12059

Behagel, J., and E. Turnhout. 2011. Democratic legitimacy in the implementation of the Water Framework Directive in the Netherlands: towards participatory and deliberative norms?
Journal of Environmental Policy \& Planning 13:297-316. http://dx. doi.org/10.1080/1523908X.2011.607002

Benson, D., O. Fritsch, H. Cook, and M. Schmid. 2014. Evaluating participation in WFD river basin management in England and Wales: processes, communities, outputs and outcomes. Land Use Policy 38:213-222. http://dx.doi.org/10.1016/ j.landusepol.2013.11.004

Beunen, R., W. G. M. van der Knaap, and G. R. Biesbroek. 2009. Implementation and integration of EU environmental directives: experiences from the Netherlands. Environmental Policy and Governance 19:57-69. http://dx.doi.org/10.1002/eet.495

Bithas, K., A. Kollimenakis, G. Maroulis, and Z. Stylianidou. 2014. The Water Framework Directive in Greece. Estimating the environmental and resource cost in the water districts of Western and Central Macedonia: methods, results and proposals for water pricing. Procedia Economics and Finance 8:73-82. http://dx.doi. org/10.1016/S2212-5671(14)00065-3

Blackstock, K. L. 2009. Between a rock and a hard place: incompatible objectives at the heart of river basin planning? Water Science \& Technology 59:425-431. http://dx.doi. org/10.2166/wst.2009.879

Blackstock, K. L., J. Dunglinson, R. Dilley, K. Matthews, M. Futter, and K. Marshall. 2009. Climate proofing Scottish river basin planning - a future challenge. Environmental Policy and Governance 19:374-387. http://dx.doi.org/10.1002/eet.522

Blackstock, K. L., K. A. Waylen, J. Dunglinson, and K. M. Marshall. 2012. Linking process to outcomesinternal and external criteria for a stakeholder involvement in river basin management planning. Ecological Economics 77:113-122.

Blackstock, K. L., K. A. Waylen, K. M. Marshall, and J. Dunglinson. 2014. Hybridity of representation: insights from river basin management planning in Scotland. Environment and Planning C: Government and Policy 32:549-566. http://dx.doi. org/10.1068/c11261

Borowski, I., J.-P. Le Bourhis, C. Pahl-Wostl, and B. Barraqué. 2008. Spatial misfit in participatory river basin management: effects on social learning, a comparative analysis of German and French case studies. Ecology and Society 13(1):7. [online] URL: http://www.ecologyandsociety.org/vol13/iss 1/art7

Börzel, T. A. 1999. Towards convergence in Europe? Institutional adaptation to Europeanization in Germany and Spain Journal of Common Market Studies 37:573-596.

Bourblanc, M., A. Crabbé, D. Liefferink, and M. Wiering. 2013. The marathon of the hare and the tortoise: implementing the EU Water Framework Directive. Journal of Environmental Planning and Management 56:1449-1467. http://dx.doi.org/10.1080/09640568.2012.726197

Carter, J., and J. Howe. 2006. Stakeholder participation and the Water Framework Directive: the case of the Ribble Pilot. Local Environment 11:217-231. http://dx.doi.org/10.1080/13549830600558564

Carter, J. G. 2007. Spatial planning, water and the Water Framework Directive: insights from theory and practice. Geographical Journal 173:330-342. http://dx.doi.org/10.1111/ j.1475-4959.2007.00257.x 
Checkel, J. T. 2001. Why comply? Social learning and European identity change. International Organization 55:553-588. http://dx. doi.org/10.1162/00208180152507551

Crabtree, B., S. Kelly, H. Green, G. Squibbs, and G. Mitchell. 2009. Water Framework Directive catchment planning: a case study apportioning loads and assessing environmental benefits of programme of measures. Water Science \& Technology 59:407-416. http://dx.doi.org/10.2166/wst.2009.875

De Stefano, L., P. Martínez-Santos, F. Villarroya, D. Chico, and L. Martínez-Cortina. 2013. Easier said than done? The establishment of baseline groundwater conditions for the implementation of the Water Framework Directive in Spain. Water Resources Management 27:2691-2707. http://dx.doi. org/10.1007/s11269-013-0311-6

de Toffol, S., S. Achleitner, C. Engelhard, and W. Rauch. 2005. Challenges in the implementation of the Water Framework Directive: case study of the Alpine river Drau, Austria. Water Science \& Technology 52:243-250.

Dehnhardt, A. 2013. Decision-makers' attitudes towards economic valuation - a case study of German water management authorities. Journal of Environmental Economics and Policy 2:201-221. http://dx.doi.org/10.1080/21606544.2013.766483

Dehnhardt, A. 2014. The influence of interests and beliefs on the use of environmental cost-benefit analysis in water policy: the case of German policy-makers. Environmental Policy and Governance 24:391-404. http://dx.doi.org/10.1002/eet.1656

DeLeon, P. 1999. The missing link revisited: contemporary implementation research. Policy Studies Review 16:311-339. http://dx.doi.org/10.1111/j.1541-1338.1999.tb00887.x

Demetropoulou, L., N. Nikolaidis, V. Papadoulakis, K. Tsakiris, T. Koussouris, N. Kalogerakis, K. Koukaras, A. Chatzinikolaou, and K. Theodoropoulos. 2010. Water Framework Directive implementation in Greece: introducing participation in water governance - the case of the Evrotas River Basin Management Plan. Environmental Policy and Governance 20:336-349. http://dx. doi.org/10.1002/eet.553

Dieperink, C., G. T. Raadgever, P. P. J. Driessen, A. A. H. Smit, and H. F. M. W. Van Rijswick. 2012. Ecological ambitions and complications in the regional implementation of the Water Framework Directive in the Netherlands. Water Policy 14:160-173. http://dx.doi.org/10.2166/wp.2011.223

Drazkiewicz, A., E. Challies, and J. Newig. 2015. Public participation and local environmental planning: testing factors influencing decision quality and implementation in four case studies from Germany. Land Use Policy 46:211-222. http://dx.doi. org/10.1016/j.landusepol.2015.02.010

Earle, R., and S. Blacklocke. 2008. Master plan for Water Framework Directive activities in Ireland leading to river basin management plans. Desalination 226:134-142. http://dx.doi. org/10.1016/j.desal.2007.02.103

Estrela, T. 2011. The EU WFD and the river basin management plans in Spain. Water Management 164:397-404. http://dx.doi. org/10.1680/wama.1000005

European Commission. 2003. Common implementation strategy for the Water Framework Directive (2000/60/EC). Guidance
Document No. 8. Public Participation in Relation to the Water Framework Directive. Office for Official Publications of the European Communities, Luxembourg.

European Commission. 2007. Towards sustainable water management in the European Union-first stage in the implementation of the Water Framework Directive 2000/60/EC. Communication from the Commission. COM(2007) 128 final. European Commission, Brussels, Belgium.

European Commission. 2009b. Common implementation strategy for the Water Framework Directive (2000/60/EC). Guidance Document No. 24. River Basin Management in a Changing Climate. Office for Official Publications of the European Communities, Luxembourg.

European Commission. 2009a. Report from the Commission to the European Parliament and the Council in accordance with Article 18.3 of the Water Framework Directive 2000/60/EC on Programmes for Monitoring of Water Status. COM(2009) 156 final. European Commission, Brussels, Belgium.

European Commission. 2012b. A blueprint to safeguard Europe's water resources. $\mathrm{COM}(2012) 673$ final. European Commission, Brussels, Belgium.

European Commission. 2012a. Report from the Commission to the European Parliament and the Council on the implementation of the Water Framework Directive (2000/60/EC) river basin management plans. COM(2012) 670 final. European Commission, Brussels, Belgium.

European Commission. 2015. Communication from the Commission to the European Parliament and the Council. The Water Framework Directive and the Floods Directive: actions towards the 'good status' of EU water and to reduce flood risks. $\operatorname{COM}(2015) 120$ final. European Commission, Brussels, Belgium.

Exadaktylos, T., and C. M. Radaelli. 2009. Research design in European studies: the case of Europeanization. Journal of Common Market Studies 47:507-530. http://dx.doi.org/10.1111/ j.1468-5965.2009.00820.x

Eyre-Walker, A., and N. Stoletzki. 2013. The assessment of science: the relative merits of post-publication review, the impact factor, and the number of citations. PLoS Biology 11: $\underline{\mathrm{http}: / / \mathrm{dx}}$. doi.org/10.1371/journal.pbio.1001675

Falkner, G., and O. Treib. 2008. Three worlds of compliance or four? The EU-15 compared to new member states. Journal of Common Market Studies 46:293-313. http://dx.doi.org/10.1111/ j.1468-5965.2007.00777.x

Falkner, G., O. Treib, M. Hartlapp, and S. Leiber. 2005. Complying with Europe: EU harmonisation and soft law in the member states. Cambridge University Press, Cambridge, UK. http://dx.doi. org/10.1017/cbo9780511491931

Feuillette, S., H. Levrel, B. Boeuf, S. Blanquart, O. Gorin, G. Monaco, B. Penisson, and S. Robichon. 2016. The use of costbenefit analysis in environmental policies: some issues raised by the Water Framework Directive implementation in France. Environmental Science \& Policy 57:79-85. http://dx.doi. org/10.1016/j.envsci.2015.12.002 
Flynn, B., and L. Kröger. 2003. Can policy learning really improve implementation? Evidence from Irish responses to the Water Framework Directive. European Environment 13:150-163. http:// dx.doi.org/10.1002/eet.320

Franzén, F., M. Hammer, and B. Balfors. 2015. Institutional development for stakeholder participation in local water management - an analysis of two Swedish catchments. Land Use Policy 43:217-227. http://dx.doi.org/10.1016/j.landusepol.2014.11.013

Fritsch, O., and D. Benson. 2013. Integrating the principles of integrated water resources management? River basin planning in England and Wales. International Journal of Water Governance 1:265-284. http://dx.doi.org/10.7564/13-IJWG7

Garand, J. C., M. W. Giles, A. Blais, and I. Mclean. 2009. Political science journals in comparative perspective: evaluating scholarly journals in the United States, Canada, and the United Kingdom. PS: Political Science \& Politics 42:695-717. http://dx.doi. org/10.1017/s1049096509990205

Gerring, J. 2012. Mere description. British Journal of Political Science 42:721-746. http://dx.doi.org/10.1017/S0007123412000130

Giles, M. W., and J. C. Garand. 2007. Ranking political science journals: reputational and citational approaches. PS: Political Science \& Politics 40:741-751. http://dx.doi.org/10.1017/ $\underline{\mathrm{s} 1049096507071181}$

Gómez-Limón, J. A., and J. Martin-Ortega. 2013. The economic analysis in the implementation of the Water-Framework Directive in Spain. International Journal of River Basin Management 11:301-310. http://dx.doi.org/10.1080/15715124.2013.823977

Gooch, G. D., and S. Baggett. 2013. IWRM in the Swedish context: a voluntary move to IWRM principles or a legal necessity to comply with the European Union Water Framework Directive? International Journal of Water Governance 1:361-378. http://dx. doi.org/10.7564/13-IJWG10

Grant, W., D. Matthews, and P. Newell. 2000. The effectiveness of European Union environmental policy. Macmillan, Houndmills, Basingstoke, UK. http://dx.doi.org/10.1057/9780333981405

Grimeaud, D. 2001. Reforming EU water law: towards sustainability? European Environmental Law Review 10:41-51.

Grimeaud, D. 2004. The EC Water Framework Directive-an instrument for integrated water policy. Review of European Community \& International Environmental Law 13:27-39. http:// dx.doi.org/10.1111/j.1467-9388.2004.00381.x

Hammer, M., B. Balfors, U. Mörtberg, M. Petersson, and A. Quin. 2011. Governance of water resources in the phase of change: a case study of the implementation of the EU Water Framework Directive in Sweden. Ambio 40:210-220. http://dx.doi. org/10.1007/s13280-010-0132-2

Hanley, N., and A. R. Black. 2006. Cost-benefit analysis and the Water Framework Directive in Scotland. Integrated Environmental Assessment and Management 2:156-165.

Hartlapp, M. 2009. Implementation of EU social policy directives in Belgium: what matters in domestic politics? Journal of European Integration 31:467-488. http://dx.doi.org/10.1080/070$\underline{36330902920051}$
Haverland, M. 2000. National adaptation to European integration: the importance of institutional veto points. Journal of Public Policy 20:83-103. http://dx.doi.org/10.1017/S0143814X00000763

Haverland, M., and M. Romeijn. 2007. Do member states make European policies work? Analysing the EU transposition deficits. Public Administration 85:57-778. http://dx.doi.org/10.1111/ j.1467-9299.2007.00670.x

Hedelin, B., and M. Lindh. 2008. Implementing the EU Water Framework Directive - prospects for sustainable water planning in Sweden. European Environment 18:327-344. http://dx.doi. org/10.1002/eet.489

Hernández-Mora, N., and A. Ballester. 2011. Public participation and the role of social networks in the implementation of the Water Framework Directive in Spain. Ambientalia

Hill, M., and P. Hupe. 2002. Implementing public policy: governance in theory and practice. Sage, London, UK.

Hophmayer-Tokich, S., and Y. Krozer. 2008. Public participation in rural area water management: experiences from the North Sea countries in Europe. Water International 33:243-257. http://dx. doi.org/10.1080/02508060802027604

Howarth, W. 2009. Aspirations and realities under the Water Framework Directive: proceduralisation, participation and practicalities. Journal of Environmental Law 21:391-417. http:// dx.doi.org/10.1093/jel/eqp019

Hüesker, F., and T. Moss. 2015. The politics of multi-scalar action in river basin management: implementing the EU Water Framework Directive (WFD). Land Use Policy 42:38-47. http:// dx.doi.org/10.1016/j.landusepol.2014.07.003

Ioris, A. A. R. 2012. The political geography of environmental regulation: implementing the Water Framework Directive in the Douro River Basin, Portugal. Scottish Geographical Journal 128:1-23. http://dx.doi.org/10.1080/14702541.2012.676667

Ioris, A. A. R. 2015. The prospects for the water management framework in the Douro, Portugal. European Urban and Regional Studies 22:316-328. http://dx.doi.org/10.1177/0969776412474588

Irvine, K., and S. O'Brien. 2009. Progress on stakeholder participation in the implementation of the Water Framework Directive in the Republic of Ireland. Biology and Environment: Proceedings of the Royal Irish Academy 109b:365-376. http://dx. doi.org/10.3318/bioe.2009.109.3.365

Jonsson, A. 2005. Public participation in water resources management: stakeholder voices on degree, scale, potential, and methods in future water management. Ambio 34:95-500. http:// dx.doi.org/10.1579/0044-7447-34.7.495

Jordan, A. 1999. The implementation of EU environmental policy: a policy problem without a political solution? Environment and Planning C: Government and Policy 17:69-90. http://dx.doi. org/10.1068/c170069

Junier, S. J., and E. Mostert. 2012. The implementation of the Water Framework Directive in the Netherlands: does it promote integrated management? Physics and Chemistry of the Earth, Parts A/B/C 47-48:2-10. http://dx.doi.org/10.1016/j.pce.2011.08.018 
Kaeding, M. 2008. Lost in translation or full steam ahead: the transposition of EU transport directives across member states. European Union Politics 9:115-143. http://dx.doi. org/10.1177/1465116507085959

Kaika, M. 2003. The Water Framework Directive: a new directive for a changing social, political and economic European framework. European Planning Studies 11:299-316. http://dx.doi. org/10.1080/09654310303640

Kaika, M., and B. Page. 2003. The EU Water Framework Directive: part 1. European policy-making and the changing topography of lobbying. European Environment 13:314-327. http://dx.doi.org/10.1002/eet.331

Kallis, G. 2005. Beyond limits and efficiency, what? Assessing developments in EU water policy. International Journal of Water 3:121-145. http://dx.doi.org/10.1504/IJW.2005.007282

Kallis, G., and D. Butler. 2001. The EU Water Framework Directive: measures and implications. Water Policy 3:125-142. http://dx.doi.org/10.1016/S1366-7017(01)00007-1

Kanakoudis, V., and S. Tsitsifli. 2010. On-going evaluation of the WFD 2000/60/EC implementation process in the European Union, Seven years after its launch: are we behind schedule? Water Policy 12:70-91. http://dx.doi.org/10.2166/wp.2009.092

Kanakoudis, V., S. Tsitsifli, and T. Azariadi. 2015. Overview of the river basin management plans developed in Greece under the context of the Water Framework Directive 2000/60/EC focusing on the economic analysis. Water Resources Management 29:3149-3174. http://dx.doi.org/10.1007/s11269-015-0988-9

Kastens, B., and J. Newig. 2007. The Water Framework Directive and agricultural nitrate pollution: will great expectations in Brussels be dashed in Lower Saxony? European Environment 17:231-246. http://dx.doi.org/10.1002/eet.446

Kastens, B., and J. Newig. 2008. Will participation foster the successful implementation of the Water Framework Directive? The case of agricultural groundwater protection in Northwest Germany. Local Environment 13:27-41. http://dx.doi. org/10.1080/13549830701581713

Keessen, A. M., J. J. H. van Kempen, M. van Rijswick, J. Robbe, and C. W. Backes. 2010. European river basin districts: are they swimming in the same implementation pool? Journal of Environmental Law 22:197-221. http://dx.doi.org/10.1093/jel/ $\underline{\text { eqq003 }}$

Keskitalo, E. C. H., and M. Pettersson. 2012. Implementing multi-level governance? The legal basis and implementation of the EU Water Framework Directive for forestry in Sweden. Environmental Policy and Governance 22:90-103. http://dx.doi. org/10.1002/eet.1574

Kirk, E. A., A. D. Reeves, and K. L. Blackstock. 2007. Path dependency and the implementation of environmental regulation. Environment and Planning C: Government and Policy 25:250-268. http://dx.doi.org/10.1068/c0512j

Knill, C. 2001. The Europeanisation of national administrations: patterns of institutional change and persistence. Cambridge University Press, Cambridge, UK. http://dx.doi.org/10.1017/ cbo9780511491986
Koontz, T. M., and J. Newig. 2014b. Cross-level information and influence in mandated participatory planning: alternative pathways to sustainable water management in Germany's implementation of the EU Water Framework Directive. Land Use Policy 38:594-604. http://dx.doi.org/10.1016/j.landusepol.2014.01.005

Koontz, T. M., and J. Newig. 2014a. From planning to implementation: top-down and bottom-up approaches for collaborative watershed management. Policy Studies Journal 42:416-442. http://dx.doi.org/10.1111/psj.12067

Kouw, M. 2014. Designing communication: politics and practices of participatory water quality governance. International Journal of Water Governance 4:37-52.

Kowalczak, P., P. Matczak, and L. Slavikova. 2013. Institutional evolution in water management in the Czech Republic and Poland. International Journal of Water Governance 1:307-322. http://dx.doi.org/10.7564/13-IJWG8

Lam, J. C. K., R. M. Walker, and P. Hills. 2012. Interdisciplinarity in sustainability studies: a review. Sustainable Development 22:158-176. http://dx.doi.org/10.1002/sd.533

Larsen, S. V. 2011. Risk as a challenge in practice: investigating climate change in water management. Regional Environmental Change 11:111-122. http://dx.doi.org/10.1007/s10113-010-0123-7

Laurenceau, M., F. Destandau, and A. Rozan. 2009. A transaction cost approach to assess the Water Framework Directive implementation. Transactions on Ecology and the Environment 125:567-578. http://dx.doi.org/10.2495/WRM090501

Liefferink, D., M. Wiering, and Y. Uitenboogaart. 2011. The EU Water Framework Directive: a multi-dimensional analysis of implementation and domestic impact. Land Use Policy 28:712-722. http://dx.doi.org/10.1016/j.landusepol.2010.12.006

Lundmark, C., and G. Jonsson. 2013. Prospects for learning in river management: exploring the initial implementation of the Water Framework Directive in a Swedish river basin. Environmental Education Research 20:161-176. http://dx.doi. org/10.1080/13504622.2013.780585

Lundqvist, L. J. 2004. Integrating Swedish water resource management: a multi-level governance trilemma. Local Environment 9:413-424. http://dx.doi.org/10.1080/1354983042000255324

Maganda, C. 2013. The implementation of the European Water Framework Directive in Luxembourg: regional compliance vs. cross-border cooperation? International Journal of Water Governance 1:403-426. http://dx.doi.org/10.7564/13-IJWG15

Martin-Ortega, J. 2012. Economic prescriptions and policy applications in the implementation of the European Water Framework Directive. Environmental Science \& Policy 24:83-91. http://dx.doi.org/10.1016/j.envsci.2012.06.002

Mastenbroek, E. 2005. EU compliance: still a 'black hole'? Journal of European Public Policy 12:1103-1120. http://dx.doi. org/10.1080/13501760500270869

May, P. J. 1992. Policy learning and failure. Journal of Public Policy 12:331-354. http://dx.doi.org/10.1017/S0143814X00005602

Medd, W., and S. Marvin. 2007. Strategic intermediation: between regional strategy and local practice. Sustainable Development 15:318-327. http://dx.doi.org/10.1002/sd.345 
Meyer, C., and A. Thiel. 2012. Institutional change in water management collaboration: implementing the European Water Framework Directive in the German Odra River Vasin. Water Policy 14:625-646. http://dx.doi.org/10.2166/wp.2012.011

Moren-Abat, M., and A. Rodriguez-Roldan. 2012. The challenges of implementing the Water Framework Directive in Spain. International Journal of Water Resources Development 28:13-18. http://dx.doi.org/10.1080/07900627.2012.640606

Moss, B. 2008. The Water Framework Directive: total environment or political compromise? Science of the Total Environment 400:32-41. http://dx.doi.org/10.1016/j.scitotenv.2008.04.029

Moss, T. 2004. The governance of land use in river basins: prospects for overcoming problems of institutional interplay with the EU Water Framework Directive. Land Use Policy 21:85-94. http://dx.doi.org/10.1016/j.landusepol.2003.10.001

Moss, T. 2012. Spatial fit, from panacea to practice: implementing the EU Water Framework Directive. Ecology and Society 17(3):2. http://dx.doi.org/10.5751/ES-04821-170302

Mylopoulos, Y. A., and E. G. Kolokytha. 2008. Integrated water management in shared water resources: the EU Water Framework Directive implementation in Greece. Physics and Chemistry of the Earth 33:347-353. http://dx.doi.org/10.1016/j.pce.2008.02.031

Neef, A. 2008. Lost in translation: the participatory imperative and local water governance in North Thailand and Southwest Germany. Water Alternatives 1:89-110.

Newig, J., E. Challies, N. Jager, and E. Kochskämper. 2014. What role for public participation in implementing the EU Floods Directive? A comparison with the Water Framework Directive, early evidence from Germany and a research agenda. Environmental Policy and Governance 24:275-288. http://dx.doi. org/10.1002/eet.1650

Newig, J., and O. Fritsch. 2009. Environmental governance: participatory, multi-level-and effective? Environmental Policy and Governance 19:197-214. http://dx.doi.org/10.1002/eet.509

Newig, J., V. Gaube, K. Berkhoff, K. Kaldrack, B. Kastens, J. Lutz, B. Schlußmeier, H. Adensam, and H. Haberl. 2008. The role of formalisation, participation and context in the success of public involvement mechanisms in resource management. Systemic Practice and Action Research 21:423-441. http://dx.doi. org/10.1007/s11213-008-9113-9

Newson, M. 2011. Rivers in trust: stakeholders and delivery of the EU Water Framework Directive. Water Management 164:433-440. http://dx.doi.org/10.1680/wama.2011.164.8.433

Nielsen, H. Ø., P. Frederiksen, H. Saarikoski, A.-M. Rytkönen, and A. B. Pedersen. 2013. How different institutional arrangements promote integrated river basin management: evidence from the Baltic Sea Region. Land Use Policy 30:437-445. http://dx.doi.org/10.1016/j.landusepol.2012.04.011

O’Toole., L. J. 1986. Policy recommendations for multi-actor implementation: an assessment of the field. Journal of Public Policy 6:181-210. http://dx.doi.org/10.1017/S0143814X00006486

Parés, M. 2011. River basin management planning with participation in Europe: from contested hydro-politics to governance-beyond-the-state. European Planning Studies 19:457-478. http://dx.doi.org/10.1080/09654313.2011.548454

Parés, M., Q. Brugué, J. Espluga, J. Miralles, and A. Ballester. 2015. The strengths and weaknesses of deliberation on river basin management planning: analysing the Water Framework Directive implementation in Catalonia (Spain). Environmental Policy and Governance 25:97-110. http://dx.doi.org/10.1002/eet.1662

Plümper, T. 2007. Academic heavy-weights: the 'relevance' of political science journals. European Political Science 6:41-50. http://dx.doi.org/10.1057/palgrave.eps. 2210112

Poteete, A. R., and E. Ostrom. 2008. Fifteen years of empirical research on collective action in natural resource management: struggling to build large- $\mathrm{N}$ databases based on qualitative research. World Development 36:176-195. http://dx.doi. org/10.1016/j.worlddev.2007.02.012

Pressman, J. L., and A. Wildavsky. 1984. Implementation: how great expectations in Washington are dashed in Oakland. University of California Press, Berkeley, California, USA.

Raadgever, G. T., C. Dieperink, P. P. J. Driessen, A. A. H. Smit, and H. F. M. W. van Rijswick. 2011. Uncertainty management strategies: lessons from the regional implementation of the Water Framework Directive in the Netherlands. Environmental Science \& Policy 14:64-75. http://dx.doi.org/10.1016/j.envsci.2010.11.001

Rahaman, M. M., O. Varis, and T. Kajander. 2004. EU Water Framework Directive vs. integrated water resources management: the seven mismatches. Water Resources Development 20:564-575. http://dx.doi.org/10.1080/07900620412331319199

Richter, S., J. Völker, D. Borchardt, and V. Mohaupt. 2013. The Water Framework Directive as an approach for integrated water resources management: results from the experiences in Germany on implementation, and future perspectives. Environmental Earth Sciences 69:719-728. http://dx.doi.org/10.1007/s12665-013-2399-7

Risse, T., M. Green Cowles, and J. Caporaso. 2001. Europeanization and domestic change: introduction. Pages 1-20 in M. Green Cowles, J. Caporaso, and T. Risse, editors. Transforming Europe: Europeanization and domestic change. Cornell University Press, Ithaca, New York, USA.

Slavíková, L., and J. Jílková. 2011. Implementing the public participation principle into water management in the Czech Republic: a critical analysis. Regional Studies 45:545-557. http:// dx.doi.org/10.1080/00343400903380390

Spiller, M., B. S. McIntosh, R. A. F. Seaton, and P. J. Jeffrey. 2012. An organisational innovation perspective on change in water and wastewater systems - the implementation of the Water Framework Directive in England and Wales. Urban Water Journal 9:113-128. http://dx.doi.org/10.1080/1573062X.2011.652129

Thaler, T., B. Boteler, T. Dworak, S. Holen, and M. Lago. 2014. Investigating the use of environmental benefits in the policy decision process: a qualitative study focusing on the EU water policy. Journal of Environmental Planning and Management 57:1515-1530. http://dx.doi.org/10.1080/09640568.2013.816271

Theesfeld, I., and C. Schleyer. 2013. Germany's light version of integrated water resources management. Environmental Policy and Governance 23:130-144. http://dx.doi.org/10.1002/eet.1602 
Thiel, A. 2014. Rescaling of resource governance as institutional change: explaining the transformation of water governance in Southern Spain. Environmental Policy and Governance 24:289-306. http://dx.doi.org/10.1002/eet.1644

Thiel, A. 2015. Constitutional state structure and scalar reorganization of natural resource governance: the transformation of polycentric water governance in Spain, Portugal and Germany. Land Use Policy 45:176-188. http://dx.doi.org/10.1016/j. landusepol.2015.01.012

Thiel, A., and C. Egerton. 2011. Re-scaling of resource governance as institutional change: the case of water governance in Portugal. Journal of Environmental Planning and Management 54:383-402. http://dx.doi.org/10.1080/09640568.2010.507936

Thomson, R. 2007. Time to comply: national responses to six EU labour market directives revisited. West European Politics 30:987-1008. http://dx.doi.org/10.1080/01402380701617407

van der Arend, S., and J. Behagel. 2011. What participants do: a practice based approach to public participation in two policy fields. Critical Policy Studies 5:169-186. http://dx.doi. org/10.1080/19460171.2011.576529

van der Heijden, J., and E. ten Heuvelhof. 2012. The mechanics of virtue: lessons on public participation from implementing the Water Framework Directive in the Netherlands. Environmental Policy and Governance 22:177-188. http://dx.doi.org/10.1002/ $\underline{\text { eet. } 1583}$

van der Heijden, J., and E. ten Heuvelhof. 2013. Coping with mandated public participation: the case of implementing the EU Water Framework Directive in the Netherlands. Perspectives on European Politics and Society 14:403-417. http://dx.doi. org/10.1080/15705854.2013.772722

van der Heijden, J., E. ten Heuvelhof, B. Broekhans, S. van der Arend, E. van Bueren, C. Harteveld, and T. van Ruijven. 2014. Contrasting stories on overcoming governance challenges: the implementation of the EU Water Framework Directive in the Netherlands. Local Environment 19:318-333. http://dx.doi. org/10.1080/13549839.2013.790349

van der Veeren, R. 2010. Different cost-benefit analyses in the Netherlands for the European Water Framework Directive. Water Policy 12:746-760. http://dx.doi.org/10.2166/wp.2010.108

Watson, N., H. Deeming, and R. Treffny. 2009. Beyond bureaucracy? Assessing institutional change in the governance of Water in England. Water Alternatives 2:448-460.

Watson, N., and J. Howe. 2006. Implementing the EU Water Framework Directive: experiences of participatory planning in the Ribble Basin, North West England. Water International 31:472-487. http://dx.doi.org/10.1080/02508060608691951

Waylen, K. A., K. L. Blackstock, K. B. Marshall, and J. Dunglinson. 2015. Participation-prescription tension in natural resource management: the case of diffuse pollution in Scottish water management. Environmental Policy and Governance 25:111-124. http://dx.doi.org/10.1002/eet.1666
Woods, D. 2008. Stakeholder involvement and public participation: a critique of Water Framework Directive arrangements in the United Kingdom. Water and Environment Journal 22:258-264. http://dx.doi.org/10.1111/j.1747-6593.2008.00136. $\underline{\mathrm{x}}$

Young, O. R. 2002. The institutional dimensions of environmental change: fit, interplay, and scale. MIT Press, Cambridge, Massachusetts, USA. 


\begin{tabular}{|c|c|c|c|}
\hline NAME & TYPE & DESCRIPTION & COMMENT \\
\hline REFERENCE & nominal & Short bibliographic reference in 'Author (Year)' format & \\
\hline PUBLICATION YEAR & numerical & Publication year of article & \\
\hline NO. OF AUTHORS & numerical & Number of authors of article & \\
\hline AUTHOR 1 COUNTRY & nominal & Country of first author & \\
\hline AUTHOR 1 INSTITUTION & nominal & School, department, institute and/or university of first author & \\
\hline AUTHOR 1 PROFESSION & binary & Professional affiliation of first author, choose from: academic, practitioner & More than one response possible \\
\hline AUTHOR 2 COUNTRY & nominal & Country of second author & \\
\hline AUTHOR 2 INSTITUTION & nominal & School, department, institute and/or university of second author & \\
\hline AUTHOR 2 PROFESSION & binary & Professional affiliation of second author, choose from: academic, practitioner & More than one response possible \\
\hline AUTHOR 3 COUNTRY & nominal & Country of third author & \\
\hline AUTHOR 3 INSTITUTION & nominal & School, department, institute and/or university of third author & \\
\hline AUTHOR 3 PROFESSION & binary & Professional affiliation of third author, choose from: academic, practitioner & More than one response possible \\
\hline AUTHOR 4 COUNTRY & nominal & Country of fourth author & \\
\hline AUTHOR 4 INSTITUTION & nominal & School, department, institute and/or university of fourth author & \\
\hline AUTHOR 4 PROFESSION & binary & Professional affiliation of fourth author, choose from: academic, practitioner & More than one response possible \\
\hline OTHER AUTHORS COUNTRY & nominal & Country of other authors & \\
\hline OTHER AUTHORS INSTITUTION & nominal & School, department, institute and/or university of other authors & \\
\hline OTHER AUTHORS PROFESSION & binary & Professional affiliation of other authors, choose from: academic, practitioner & More than one response possible \\
\hline JOURNAL NAME & nominal & Journal in which the article was published & \\
\hline JOURNAL ISI SUBJECT CATEGORY & categorical & ISI subject category of the journal & More than one response possible \\
\hline CASE STUDY COUNTRIES & nominal & EU country studied & $\begin{array}{l}\text { More than one response possible, } \\
\text { 'EU27' refers to articles }\end{array}$ \\
\hline NO. OF CASE STUDY COUNTRIES & numerical & Number of EU countries studied & \\
\hline POLICY LEVEL & categorical & Policy levels studied, choose from: national, River Basin District, catchment & More than one response possible \\
\hline RBD NAME & nominal & If POLICY LEVEL includes River Basin Districts: name of River Basin District & More than one response possible \\
\hline INTERNATIONAL RBD & binary & $\begin{array}{l}\text { If POLICY LEVEL includes River Basin Districts: are these international, } \\
\text { shared river basins? Choose from: yes, no }\end{array}$ & \\
\hline INTERNATIONAL ASPECT STUDIED & binary & \begin{tabular}{|l|} 
If INTERNATIONAL RBD = yes: was this international dimension studied in \\
the article? Choose from: yes, no
\end{tabular} & \\
\hline WFD STAGE & categorical & $\begin{array}{l}\text { Temporal stage of WFD implementation, choose from: CIS pilot, transposition, } \\
\text { cycle } 1 \text {, cycle } 2\end{array}$ & $\begin{array}{l}\text { More than one response possible, } \\
\text { 'CIS pilot' refers to case studies of }\end{array}$ \\
\hline WFD ASPECT & categorical & $\begin{array}{l}\text { WFD themes addressed in article, choose from: ecological goals, economic } \\
\text { analysis, participation, planning process, policy integration, river basin }\end{array}$ & More than one response possible \\
\hline ABSTRACT & nominal & Abstract as found in the article & \\
\hline KEY WORDS & nominal & Key words as found in the article & \\
\hline AMBITION & categorical & $\begin{array}{l}\text { Nature of research question, choose from: descriptive, evaluative, evaluative } \\
\text { adhoc, causal, causal adhoc }\end{array}$ & \\
\hline THEORY & nominal & Use of concepts and theory in article & \\
\hline METHOD SECTION & categorical & Existence of statement on data and methods, choose from: yes, no, part of $x$ & $\begin{array}{l}\text { Part of } x^{\prime} \text { refers to statements on } \\
\text { data and methods made in }\end{array}$ \\
\hline LENGTH METHOD SECTION & numerical & Word count of statement on data and methods & \\
\hline CITATIONS GOOGLE SCHOLAR & numerical & Number of citations according to Google Scholar & \\
\hline CITATIONS WEB OF SCIENCE & numerical & Number of citations according to Web of Science & \\
\hline
\end{tabular}

